\title{
Synoptic Review of Theory and Practice of Diversity Management
}

\author{
Kwesi Atta Sakyi (corresponding author) \\ Head of Research \\ ZCAS University, P.O. Box 35243, Lusaka, Zambia \\ E-mail: kwesi.sakyi@zcas.edu.zm/kwesiattasakyi449@gmail.com
}

Dr Geoffrey K. Mweshi

Dean of Social Studies

ZCAS University, P. O. Box 35243, Lusaka, Zambia

E-mail: Geoffrey.Mweshi@zcas.edu.zm

David Musona

Head of Economics

ZCAS University, P. O. Box 35243, Lusaka, Zambia

E-mail: david.musona@zcas.edu.zm

\author{
Esnart Mwaba Tayali \\ $\mathrm{PhD}$ Student, University of Strathclyde, Edinburg \\ E-mail: estayali@gmail.com
}

Received: Dec. 26, 2020 Accepted: Jan. 20, $2021 \quad$ Online published: Feb. 1, 2021

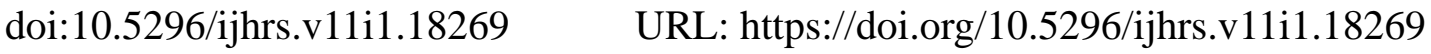

\begin{abstract}
Diversity is a topic which has gained much momentum and currency in modern academic discourse partially because of globalisation and also partially because of the increased use of information technology in global transactions. The complex operations of multinational
\end{abstract}


corporations across the globe require prudent and efficient management of employees from different backgrounds. Management of diversity means many things to many people. In this article, the authors delineate the importance, pros and cons of diversity management for firms, and also they deploy the analysis of some case study videos to bring to the fore the growing importance of the phenomenon of diversity. The authors used secondary data and qualitative analysis in their discourse. The authors reviewed literature from diverse sources to give a theoretical foundation to the article and at the same time they approached the topic in a multi-faceted manner to whet the appetite of both theoreticians and practitioners. The philosophical underpinning of their approach was based on Grounded Theory as it could be seen in the video case study narratives and in their own interpretative narrative of the subject.

Keywords: diversity, individual differences, inclusiveness, multiculturalism, tolerance, cultural intelligence, talent management, expatriates

\section{Introduction}

The topic of diversity management is itself diverse as sometimes one is not sure where to start and where to end the discussion because, as diverse as the topic of diversity is, any discussion fits it because like water, it fits any container it is put in. The topic of diversity straddles many disciplines such as Psychology, Nursing Science, Education, Child Psychology, Global Business, International Human Resource Management, International Relations, Management Science, Diplomacy, and Cultural Studies, among many others. It is therefore eclectic and overarching in nature.

The word diversity means having a variety of things or a thing that shows many differences in its characteristics (Merriam Webster Dictionary). Therefore, diversity management pertaining to human resource management, connotes that we are examining how organisations accommodate and handle their labour force that comprises people from different backgrounds, nationalities, ethnicities, professions, religious groupings, sexual orientations, political ideologies, personalities, gender, physical, mental, and social abilities and disabilities, physical make-up, among other distinguishing characteristics (Patrick \& Kumar, 2012). The topic is both relevant to domestic as well as international human resource practices.

In short, in managing diversity of the human resource, we resort to allowing the otherliness of our employees prevail as strength rather than as a weakness so that we can exploit that differentiating characteristic to add value to our activities. Diversity management is in tandem with concepts of fairness, equity, equality, gender balance, reverse discrimination, empowerment of minorities, among other concepts which seek to rectify anomalies pertaining to the management and administration of the human resource. It also enriches and supports the concept of sustainability (Omedien et al., 2012).

Table 1. Systematic Literature Review

\begin{tabular}{|c|c|c|c|c|}
\hline Serial Nu. & Author & Year & Title & $\begin{array}{c}\text { Page } \\
\text { Numbers/Viewpoint }\end{array}$ \\
\hline 1. & CFI Education & 2020 & $\begin{array}{c}\text { Diversity } \\
\text { Management }\end{array}$ & \\
\hline
\end{tabular}




\begin{tabular}{|c|c|c|c|c|}
\hline 2. & $\begin{array}{l}\text { Thomas, D.C. \& } \\
\text { Petersen, M.F. }\end{array}$ & 2015 & $\begin{array}{c}\text { Cross Cultural } \\
\text { Management-Essential } \\
\text { Concepts }\end{array}$ & \\
\hline 3. & Armstrong, M. & 2014 & $\begin{array}{c}\text { Armstrong Handbook } \\
\text { of HRM Practice }\end{array}$ & \\
\hline 4. & $\begin{array}{l}\text { Groysberg, B \& } \\
\text { Connolly, K. }\end{array}$ & 2013 & $\begin{array}{c}\text { Great Leaders who } \\
\text { make the mix } \\
\text { work-HBR }\end{array}$ & \\
\hline 5. & NYUWagner & 2010 & $\begin{array}{l}\text { Leadership, Diversity, } \\
\text { and Inclusion-Insight } \\
\text { from Scholarship }\end{array}$ & \\
\hline 6. & Mullins, L.J. & 2010 & $\begin{array}{l}\text { Management and } \\
\text { Organisational } \\
\text { Behaviour }\end{array}$ & \\
\hline 7. & $\begin{array}{l}\text { Robbins, S.P. \& } \\
\text { Judge, T.A. }\end{array}$ & 2019 & $\begin{array}{c}\text { Organisational } \\
\text { Behaviour }\end{array}$ & pp. 74-102 \\
\hline 8. & DMC PRAGUE & n.d. & $\begin{array}{c}\text { Leadership and } \\
\text { Developing Diversity } \\
\text { and Inclusion }\end{array}$ & \\
\hline 9. & $\begin{array}{l}\text { Dessler, G., } \\
\text { Rekar, M.C. \& } \\
\text { Cole, N.D. } \\
\end{array}$ & 2011 & $\begin{array}{l}\text { Management of } \\
\text { Human Resource }\end{array}$ & \\
\hline 10. & $\begin{array}{l}\text { Brewster, C. } \\
\text { Sparrow, P. , } \\
\text { Vernon, G. \& } \\
\text { Houldsworth, E. }\end{array}$ & 2011 & $\begin{array}{c}\text { International Human } \\
\text { Resource } \\
\text { Management }\end{array}$ & \\
\hline 11. & $\begin{array}{l}\text { Torrington, D., } \\
\text { Hall, L. Taylor, } \\
\text { S. \& Atkinson, } \\
\text { C. }\end{array}$ & 2011 & $\begin{array}{l}\text { Human Resource } \\
\text { Management }\end{array}$ & \\
\hline 12. & Rose, E. & 2008 & $\begin{array}{c}\text { Employment } \\
\text { Relations }\end{array}$ & \\
\hline 13. & $\begin{array}{l}\text { Schneider, S.C., } \\
\text { Barsoux, J.L. \& } \\
\text { Stahl, G.K. }\end{array}$ & 2003 & $\begin{array}{c}\text { Managing Across } \\
\text { Borders }\end{array}$ & \\
\hline 14. & $\begin{array}{l}\text { Mondy, R.W., } \\
\text { Noe, R.M. \& } \\
\text { Premeaux, S.R. }\end{array}$ & 2002 & $\begin{array}{c}\text { Human Resource } \\
\text { Management }\end{array}$ & \\
\hline 15. & Banks, K.H. & n.d. & $\begin{array}{l}\text { Diversity in } \\
\text { Leadership }\end{array}$ & \\
\hline 16. & Kamoche, K.N. & 2001 & Understanding HRM & pp.92-110 \\
\hline 17. & $\begin{array}{c}\text { Bartlett, C.A. \& } \\
\text { Ghoshal, S. }\end{array}$ & 1987 & $\begin{array}{c}\text { Managing Across } \\
\text { Borders } \\
\end{array}$ & \\
\hline 18. & Kogut, B. & 1985 & $\begin{array}{l}\text { Designing Global } \\
\text { Strategies-Profiting } \\
\text { from Operational } \\
\text { Flexibility- SMR }\end{array}$ & \\
\hline 19. & Nadler, L. & 1984 & $\begin{array}{c}\text { The Handbook of } \\
\text { Human Resource } \\
\text { Development }\end{array}$ & \\
\hline 20. & Prahalad, C.K. & 1976 & $\begin{array}{c}\text { Strategic Process in } \\
\text { MNC }\end{array}$ & \\
\hline 21. & Thompson, J.D. & 1967 & $\begin{array}{c}\text { Organisations in } \\
\text { Action }\end{array}$ & \\
\hline
\end{tabular}


Recognition of diversity at the workplace means that each employee is seen as a unique identity or entity with peculiar and unrepeatable personality traits, and is duly treated as such based on his or her age group, physical and mental ability, skills and professional background, gender, religion, sexual orientation, race, ethnicity, level of educational attainment, social class, culture, and nationality, among several variables (Schneider et al., 2013). Managing diversity means being inclusive in covering everybody when corporate policies are made. According to CFI (2020) the diversity management approach is superior to that of Affirmative Action which seeks to protect minority groups or marginalized groups. In the past, emphasis on Affirmative Action and Reverse Discrimination approaches had been counter-productive and had raised protests from majority groups (Rollinson, 2008).

However, many firms dislike adopting the diversity management approach because they see it as a voluntary option and not a statutory requirement. Besides, they see it as tedious to practise and also a costly approach to follow (Sharma, 2016). Multinational Corporations (MNCs) and multilateral institutions such as the UN, EU, FIFA and OECD, among others, have found it necessary to pursue diversity management because they deal with workforce that is varied, with employees coming from several different nationalities, professions, circumstances, and cultures (Brewster et al., 2011; Dessler et al., 2011). The increased awareness of the Declaration of Human Rights by the UN in 1948 and the drive to embrace ethical behaviour, professionalism and good corporate governance have all added impetus to the diversity drive around the globe (Bartlett \& Ghoshal, 1987).

Managing diversity also means that organisations become open-minded, flexible and innovative in the way they handle interpersonal and inter-group relationships by not using one brush to paint everyone in the same colour (Nadler, 1984; Perkins \& White, 2008; Rose, 2008). We recognise that many organisations believe in having standardized, formalized, and routine procedures in order to achieve set objectives efficiently, timeously and in an orderly and systematic manner. Certain tasks need predictability and stable environments while others subsist on chaos and turbulence (Mullins, 2010). Overall, most organisations want predictability of actions and events for planning purposes so they try to order things by using bureaucratic systems to establish procedures, systems, norms, structures, and processes to bring about conformity.

However, in a volatile and turbulent world of multinational corporations, especially for firms in the ICT business, the name of the game is creativity, innovation, and whirlwind change, the speed to market, customer-centric inclination and adaptability to rapidly changing market trends (Johnson, Scholes \& Wittington, 2013). To survive in such whirlpool environments, organisations are now resorting to Big Data Analytics, Data Science, Artificial Intelligence and Machine Learning in order to have leeway and leverage over their competitors (Robbins \& Judge, 2013; Rollinson, 2008). Others are resorting to soft approaches such as practising Corporate Social Responsibility, Corporate Governance, being ethical and embracing good corporate citizenship, declaration and publication of progressive Social Charters, and alignment of their internal value chains with networks and pipelines in the industry. The name of the game is survival and sustainability (Mullins, 2010; Rollinson, 2008; Robbins \& Judge, 2013). 
Diversity of people, places, processes, products, and quick response to price changes require that a firm should be diverse in its operations in order to cope with a plethora of market demands. A firm also has to be nimble on its feet to be able to dance like a behemoth elephant and also to stay tuned in to the environment by using market sensors and environmental scanning methods in order to gather market intelligence (cf. Rosabeth Moss Kanter, Amitai Etzioni).

\section{Methodology}

In this article, the authors examine the importance of pursuing diversity management in organisations and the need to embrace the concept in this era of rapid technological change and blurring of national boundaries due to the rapid uptake of Information Communication Technology that has led to global convergence (Robbins \& Judge, 2013; Armstrong, 2014). The authors use case studies in the educational sector as well as best practices of diversity management in some selected Multinational Corporations around the globe to buttress their discussion and analysis. The authors variously teach undergraduate and post-graduate courses in Global Business, Global Supply Chains, International Trade, International Economics, Development Economics, International Human Resource Management or Managing People across Cultural Borders, Research Methods, and Strategic Management, among many others. It is from these knowledge fields that they draw their insights expressed in this article.

The main objective of this paper is to synthesize data on the topic in a paper review format, and also to probe the topic of diversity further by contextualizing it within the multidisciplinary fields of knowledge of the authors in the Humanities and Social Sciences. The authors use both thematic analyses and interpretative approach based on secondary data analysis from reports posted by selected MNCs on their websites. Even though the authors would have loved to do some quantitative analysis, the kind of data they had anticipated existed on the website was not found so they had to change direction and settle for qualitative research.

This article is a review or overview of the literature on diversity management that combines both theoretical and empirical methods in the exegesis. The authors believe that by engaging in this kind of academic discourse, they will provide food for thought for potential researchers and at the same time provide a fresh and holistic way of looking at the phenomenon of diversity management. We will like to stress our belief that contrary to misperceptions in certain quarters, it is erroneous to conclude that quantitative research methods are superior to qualitative research methods and outcomes. Original primary field research is costly, time-consuming and not suitable for academics like us who execute humungous tasks in our daily tasks at our workplace.

The methodology adopted in this article is one based on narrative and discussion of two videos which focus on diversity case studies. Thus the methodology employed in this article is based on qualitative approach as well as the use of secondary data obtained from YouTube website, plus insights drawn by the authors from their lecturing experiences and observations. Furthermore, the approach uses the thematic method for analysis. All in all, this article adopts a multidisciplinary approach as this approach is germane to the Social Sciences in helping to 
indulge in eclectics or borrowing from many disciplines. Finally, we based the research design on the philosophical underpinning of Grounded Theory and the Interpretative approach.

\section{Theoretical Background}

According to Corporate Finance Institute (CFI) (2020) website, Diversity Management was meant to generate awareness of the need to embrace and propel acceptance of greater inclusiveness of employees from different backgrounds into the structure of the organisation, through the pursuit of deliberately-crafted policies and programmes to bring about universal inclusion (Rollinson, 2008). As the world moves from a point of divergence towards a point of convergence, facilitated by the recent advances in communication technology, the fact of divergence of cultures should not be lost on us because human beings always crave identity and the need to cling to their roots or origins. Even though the new technologies bring us together and make the world a global village, yet we should not forget the fact that we will not be changed physically by these technologies for us to be different from who we really are.

MNCs realise the need to bridge the employment gap created in the past by restrictive practices that have made the labour force of many companies and organisations unrepresentative of the global population. For example, not many Africans are found in top positions or in lucrative jobs in many MNCs or international organisations because of previous practices by these organisations and institutions to favour certain groups from certain races, and also their tendency to bond with those from Ivy League and Russell Group universities (US Bureau of Labor, 2017; Schafer et al., 2012). Also, in the past, women have been systematically marginalized and excluded from representation on boards around the world (Stegmann et al., 2012; Fassinger, 2008). All these trends are now changing as many women are now enfranchised and empowered by liberalized policies, and are pursuing courses which earlier on were gentrified or made exclusive preserves of males. The Femininism movement has been frowned upon and tagged as lowbrow sorority, hence the need to find a broader scope envelope to encapsulate and capture dissenting groups, movements and causes to be put under one big umbrella, namely universal inclusion or diversity management.

All these imbalances need to be addressed and corrected through the pursuit of and the agency of diversity management. In some countries such as Zambia, certain top jobs and businesses are restricted to only Zambian nationals, thus restricting enterprise space and stifling inflow of new ideas and capital. These are some of the restrictive environments which make the practice of diversity dicey and sometimes impracticable in these xenophobic, hostile and conservative environments.

Table 2 below lists the 17 UN SDGs which have 169 targets. They speak to many issues which pertain to managing diversity. All the Goals speak to addressing issues of economic, social, and environmental justice through the practice of embracing diversity, inclusivity, and judicious allocation and use of resources (Sachs, 2012; Espey et al., 2015; UN, 2015; ICSU/ISSC, n.d.). The UN SDGs are holistic as they encompass diversity issues at the macro and micro levels. 
Table 2. UN Sustainable Development Goals (SDGs)

1. End poverty in all its forms everywhere

2. End hunger, achieve food security and improve nutrition, promote sustainable agriculture

3. Ensure healthy lives and promote well-being for all at all ages

4. Ensure inclusive and equitable quality education and promote life-long learning opportunities for all

5. Achieve gender equality and empower all women and girls

6. Provide available and sustainable water and sanitation for all

7. Access to affordable, reliable, sustainable and modern energy for all

8. Promote sustained, inclusive and sustainable economic growth, full employment and decent work for all

9. Build resilient infrastructure, promote inclusiveness and sustainable industrialisation and foster innovation

10. Reduce inequalities within and among countries

11. Make cities and human settlements inclusive, safe, resilient and sustainable

12. Ensure sustainable consumption and production patterns

13. Take urgent action to combat climate change

14. Conserve and sustainably use oceans, seas and marine resources for sustainable development

15. Protect, restore and promote sustainable use of terrestrial ecosystems, sustainably manage forests, combat desertification, and halt and reverse land degradation, and halt biodiversity loss

16. Promote peaceful and inclusive societies for sustainable development, promote access to justice, accountability and promote strong institutions

17. Promote and build global partnerships for sustainable development

Source: UN SDG Compass (Online)

According to CFI (2020) the need to open up space for diversity management occurred in the mid-80s in the USA and it spread quickly to all parts of the world. During that time, Affirmative Action, Reverse Discrimination and Racial Equality became buzz terminologies that were bandied around a lot. However, those movements were seen to be narrow in scope so the terms Diversity Management or Universal Inclusion became the preferred substitute expressions during the Ronald Reagan era (CFI, 2020). Proponents and advocates of Diversity Management posit that Diversity Management is superior because it promotes trust, care, acceptance, inclusivity, and above all, a one happy family ambience at the workplace.

Advocates of Diversity Management (DM) in the mid-80s argued that practising Diversity Management would give the USA comparative advantage in its global trade and also help to rectify some of the injustices in the labour market in the past. We should note that Diversity Management does not only refer to having a heterogeneous labour force in one country but also having a heterogeneous labour force across global borders (CFI, 2020). 
CFI (2020) stated that there are two main forms of diversity management namely intra-national diversity management within a country and secondly cross-national diversity management across national borders. The former refers to domestic HRM (Human Resource Management) while the latter refers to IHRM (International Human Resource Management) which deals with MNCs and supra-national institutions such as the UN and the EU, among many others. CFI (2020) identified some characteristics of Diversity Management as:

- DM is voluntarily practised by organisations in their own enlightened interest without any statutory obligation to comply with. However, each country and organisation should decide for itself how rigid or lax they will go with the tenets of DM.

- DM is seen as value-addition as it helps to attract a pool of talent from all walks of life around the globe and retain them by pursuing progressive, equitable, and forward-looking HRM policies and programmes. This may seem so yet some schools of thought argue that certain elite groups like to keep their space and privacy without letting in outsiders who are seen as intruders, misfits, outliers, and erratics.

- DM helps the organisation to tap into the potential of diverse labour force from many nationalities that come with many innovative ideas and also it helps maintain a competitive environment of heightened performance. Locals in Host or Third world countries who are xenophobic-inclined may cry foul that foreigners have come to steal their jobs, forgetting the manifold blessings bestowed on them by diversity management. On the other hand, expatriate workers who experience cultural shock while working away from their countries are assisted to settle down properly where the organisation buys into DM

- DM is broader in scope and it does not draw criticism from any quarter, unlike the narrow scope of Affirmative Action and Reverse Discrimination actions in the past during the turbulent racial riots in the USA in the 60s. However, critics of DM point to the complexity and high cost of practising it by going an extra mile to accommodate every Tom, Dick and Harry. DM requires the firm to deploy considerable resources by employing specialists and experts to offer support services to handicapped staff (Beham et al., 2012; Bassett-Jones, 2005; Byars \& Rue, 1997)

- DM serves as a selling point and a public relations stunt which creates goodwill and the feel-good effect among employees who otherwise may feel discriminated against or marginalized. It builds trust internally and externally and removes all forms of prejudice, stereotyping and discrimination. However, those stakeholders with short-term view will want quick results or returns on their investment and as such they do not care about the long-term survival or sustainability of the firm, and the need to buy into diversity programmes

- DM helps with continuity and sustainability of operations as it deepens the sources of labour for the organisation by extending the labour catchment areas and labour pipelines. Antagonists of this view may point out that every country needs to be 
self-reliant and should not trust foreigners to do things for them because it will mean locals will not be able to develop internal capacities and capabilities. These are the ultra-nationalists, irredentists, xenophobes, and parochial thinkers

- DM helps to avoid high labour turnover, to avoid costly labour riots, and to mitigate litigation costs that arise from employees who sue in court for discrimination. Critics do argue that human beings will always have grouses to air out and axes to grind as if you attempt to please everybody, you end up pleasing nobody in particular

- On a macro level, embracing DM will help achieve many of the UN SDGs such as empowering girls and women, eradicating hunger and poverty, tackling unemployment, and extending life-long learning opportunities to all people everywhere (UN, 2015; Espey, et al., 2015; Sachs, 2012)

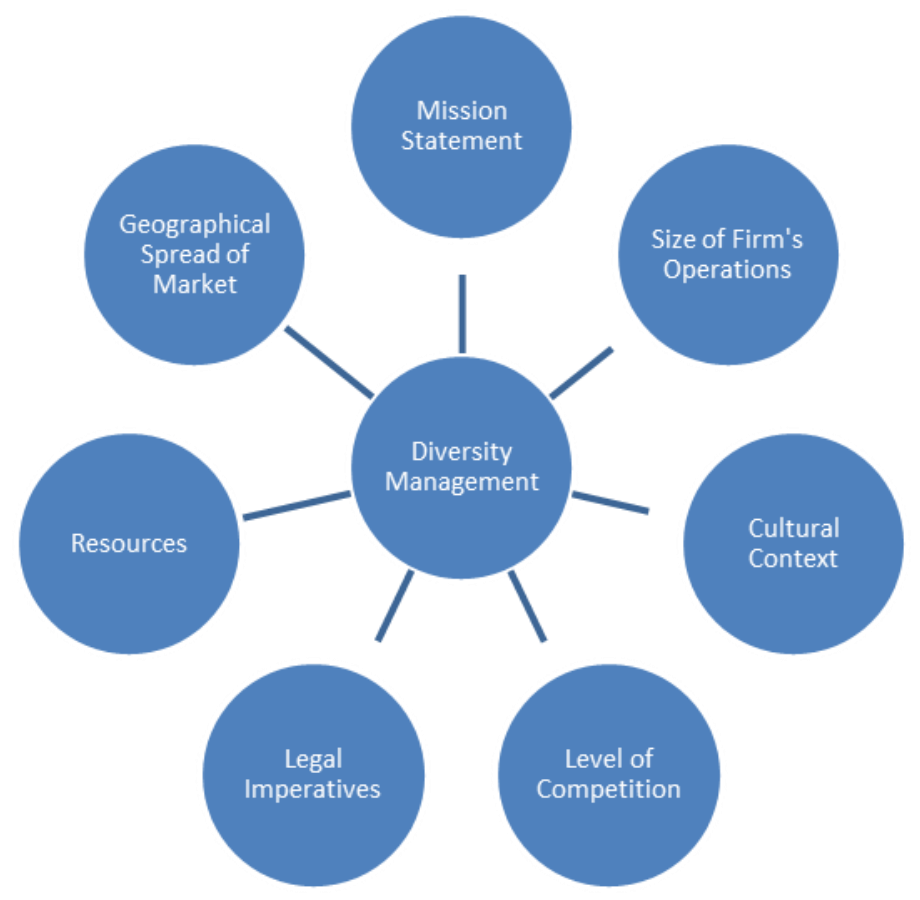

Figure 1. Factors that Influence Diversity Management (DM)

\section{Source: Authors}

Figure 1 above depicts that Diversity Management (DM) is influenced and driven by factors such as Access to Resources and Internal Capacity, Level of Competition in the Global markets faced by MNCs, Cultural Imperatives of context and content in particular countries, Legal Constraints and Imperatives which may either promote or constrain the practising of Diversity Management since DM in organisations is voluntary, Size and Level of Operations of the organisation which dictate and determine its sustainability and viability, Geographical Spread of the Market, and finally the Mission Statement and ideals or values of an entity which are professed by it. The more progressive and receptive an organisation is in embracing change, based on internal and external triggers, the more its proclivity for 
embracing Diversity Management.

We propose the following model:

$\mathrm{DM}=\mathrm{f}(\mathrm{R}, \mathrm{GS}, \mathrm{MS}, \mathrm{SFO}, \mathrm{CC}, \mathrm{LC}, \mathrm{LI})$

Where DM is Diversity Management

$\mathrm{R}$ is resources (1)

GS is geographical spread of market (2)

MS is mission statement (3)

SFO is scale of firm's operations (4)

$\mathrm{CC}$ is culture context

LI is legal imperatives (6)

and,

LC is level of market competition (7)

From observation and logical reasoning, we observe that most of these variables correlate positively with DM except in a few cases where Mission Statement, Legal Imperatives, and Culture Context may either be positively or negatively correlated with DM. These circumstances are likely to arise in deeply traditionalistic, nationalistic and conservative environments where there is resistance to change. However, this model will need to be empirically researched by future researchers.

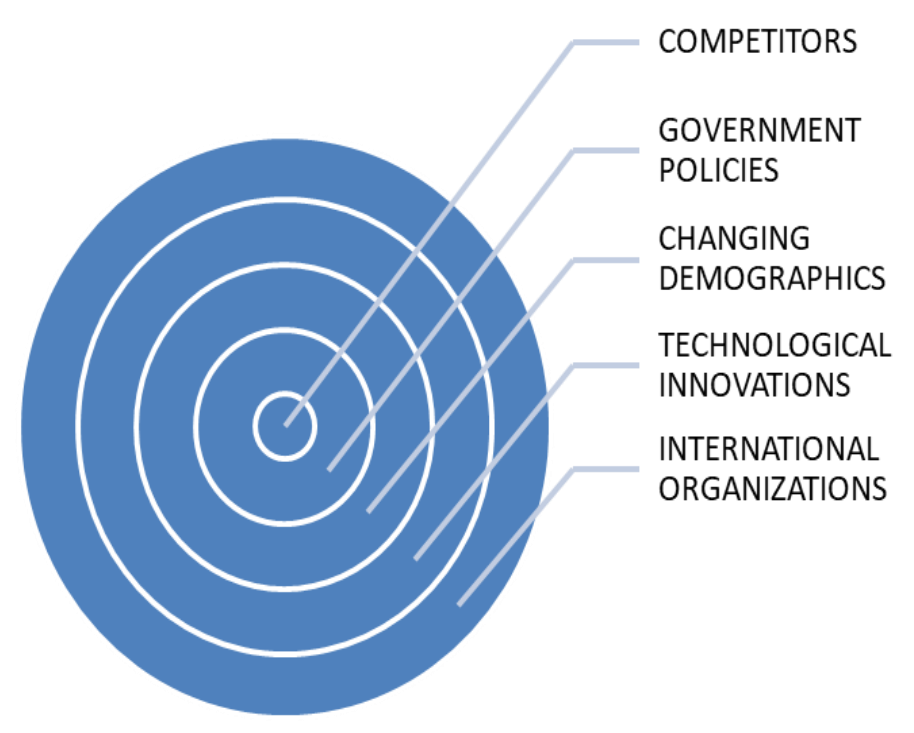

Figure 2. Diversity macro onion- externally-driven factors

Source: Authors 


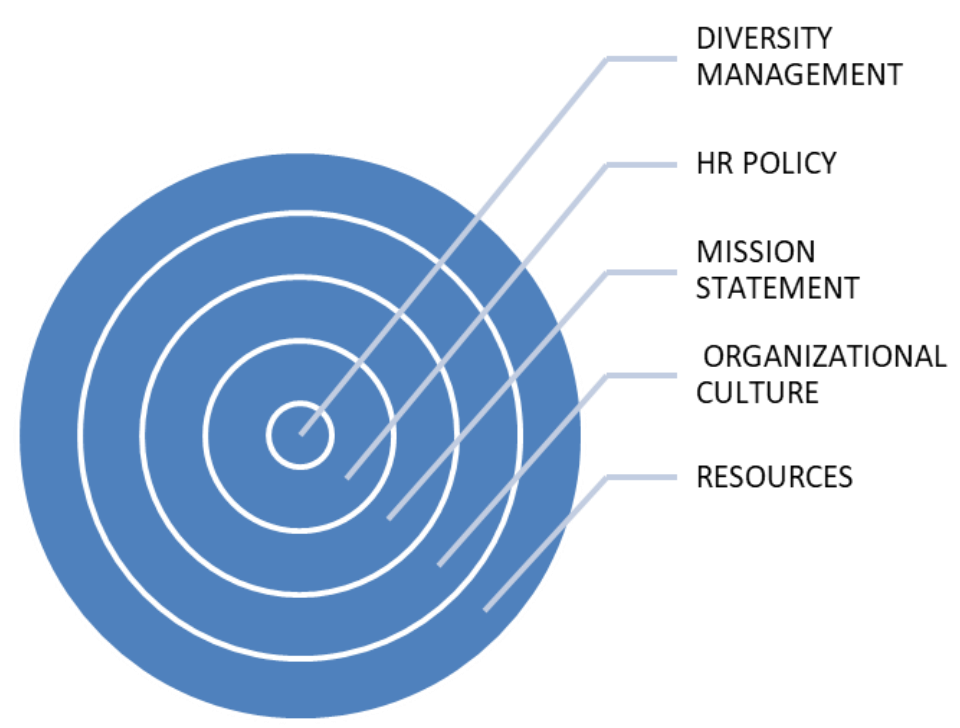

Figure 3. Diversity micro onion internally-driven factors

Source: Authors

Our model can econometrically be stated as:

$$
Y=\alpha+b_{1} X_{1}+b_{2} X_{2}-b_{3} X_{3}+b_{4} X_{4}-b_{5} X_{5}-b_{6} X_{6}+b_{7} X_{7}+\varepsilon
$$

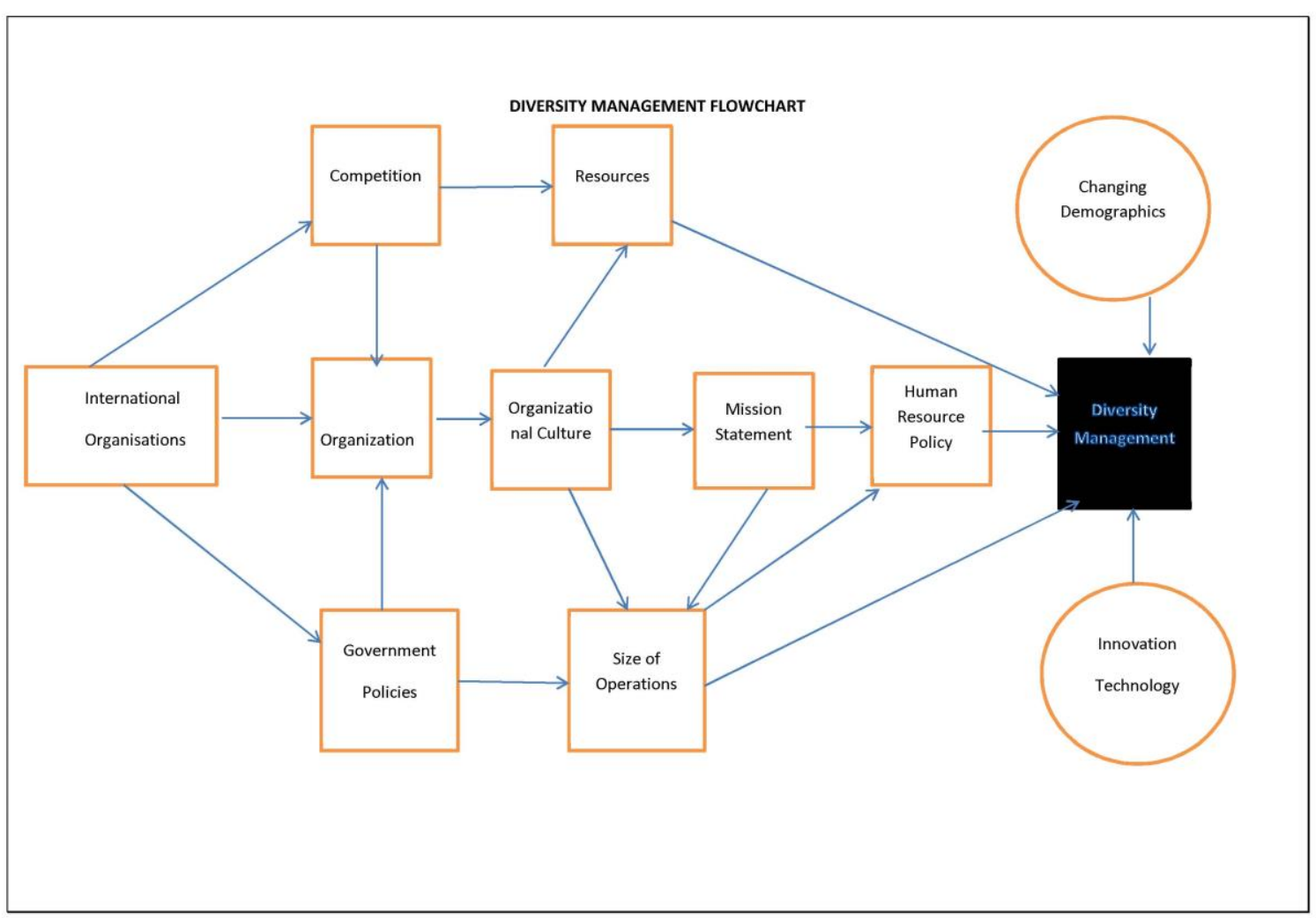

Figure 4. Conceptual model of factors that influence Diversity Management (Authors) 


\section{MInstitute ${ }_{\text {Mink }}^{\text {Macrothink }}$}

International Journal of Human Resource Studies ISSN 2162-3058 2021, Vol. 11, No. 1

Figure 4 above shows a conceptual model of the factors that influence the practice of Diversity Management in organisations. These factors can either be external or internal. The external factors are level of competition as well as the perception of external stakeholders of the organisation, changes in population dynamics, and changes in technology, government policies, and pressure from multilateral institutions. These external factors do influence what happens within organisations. The internal factors in the organisation that drive Diversity Management are the amount of resources available to the organisation, its culture and mission statement, its Human Resource policy, its structure and its size of operations.

CFI (2020) alluded to best practices that should be embraced when pursuing Diversity Management. These include the top management having shared vision about DM and being highly committed to DM ideals. CFI (2020) recommended that the organisation should beef up its talent pool by poaching talented employees from rival companies and also scouting for young, fresh, and brilliant graduates from graduate schools which should serve as incubation hubs in the labour pipeline. Furthermore, organisations are advised to create wider networks to tap ideas from them; sense what is trending in the market; attend fairs and also have open days to have interaction with clients and valued partners (Robbins \& Judge, 2013).

The organisation is advised to create many avenues for dialogue, engagement and listening to those who want to air out their views and opinions. People of similar origin should be allowed on diversity platforms to express their concerns. Finally, diversity management should be embedded in the company's objectives so that it becomes policy (CFI, 2020; Greenberg, 2010; Kearney \& Voelpel, 2012; Inegbedion et al., 2020).

CFI (2020) advocated that some symbolic and token gestures taken by top management can bring about greater awareness of DM to their employees who either feel threatened or marginalized (Rollinson, 2008; Robbins \& Judge, 2013). These token actions could include undertaking LGBT sensitization walks, celebrating independence days of workers, conducting fundraising for HIV-AIDS patients, among many other initiatives (CFI, 2020). It should be noted that in some instances, some Board of Governors may not agree to release funds for Diversity Management programmes within an organisation. In that scenario, there is nothing that can be done except when there is a national law or policy to enforce compliance with DM norms (Atiyah, 2016; Anca \& Vasquez, 2007).

Table 3. Diversity Management-Related Vocabulary (Benefits and Demerits)

\begin{tabular}{|l|l|}
\hline $\begin{array}{l}\text { DIVERSITY MANAGEMENT VOCAB } \\
\text { (Positive words) }\end{array}$ & $\begin{array}{l}\text { NON-DIVERSITY MGT. VOCAB } \\
\text { (Negative words) }\end{array}$ \\
\hline $\begin{array}{l}\text { Otherliness } \\
\text { Open Systems } \\
\text { Inclusivity }\end{array}$ & $\begin{array}{l}\text { Closed Systems } \\
\text { Narrow Dialogue Channels } \\
\text { Differentiation }\end{array}$ \\
$\begin{array}{l}\text { Rigid Procedures } \\
\text { Courteous cooperation (comity/amity) }\end{array}$ & Patronage \\
Non-gender discrimination & Paternalism \\
\hline
\end{tabular}


Reverse discrimination

Non-racial

Affirmative Action

Racial Equality

Cognitive Dissonance

Multiculturalism

Multi-racialism

Non-Aligned

Equal Opportunities Employer

Equal Work for Equal Pay

Empowerment

Engagement

Teamwork

Collegiate leadership

Shared Values and Vision

Social Charter

Holistic Approach

Ethical Behaviour

Ethics Committee

Corporate Governance

Corporate Social Responsibility

Mutual Coexistence

Flat Organisational Structure

Mentoring

Talent Management

Equity/Fairness

Transparency

Open Door Policy

Open Communication network

Simple Procedures

Flexibility

Open Dialogue Channels

Networking

Adaptive Systems

Socialization

Overarching systems

Continuous Improvement

Diffused Power Structure

High Labour Retention

High Levels of Innovation

Long Product Life Cycles

Mutual Coexistence

Interdependencies
Religious Bigotry

Ultra-Nationalism

Irredentism

Insularity

Gentrification

Closed Communication Network

Racism

Elitism

Insider-trading

Dominant Coalition

Log-rolling

Horse Trading

Nepotism

Vertical and Horizontal Conflict

Systemic Corruption

Bullying

Industrial Action

Conflict

Misogynies

Misanthropist

Whistle-blowing

Sexual Harassment

Prejudice

Stereotyping

Marginalisation

Separation

Closed Shop

Glass Ceiling/Glass Walls

Ethnocentricity

Nationalism

Complex procedures

Insideration

Egocentricity

Short-termism

Traditionalism

Centralized Power Structure

High Labour Turnover

High Levels of Customer Dissatisfaction

Dwindling Market Share

Short Product Life Cycles

Stand-Alone systems

Employee Dissatisfaction

Xenophobia 


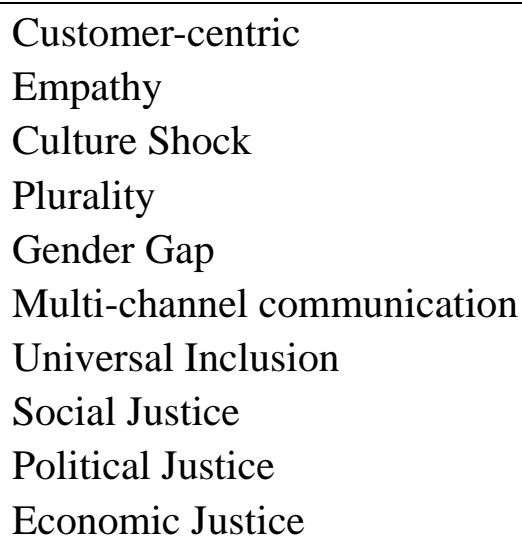

Source: Authors

Table 3 above shows compilation of vocabulary which we as authors think are likely to be closely associated with firms and organisations practising Diversity Management (DM) and those firms and organisations which are not practising it. The reader is invited to add or subtract from the list on DM on the left of the table, and those organisations not practising DM are likely to be associated with the vocabulary on the right in Table 3.

\section{Literature Review}

Saxena (2014) in her study averred that Diversity Management (DM) requires leadership commitment to the ideal so that it can lead to organisational effectiveness which will translate into higher productivity. Saxena (2014) concluded that the practice of DM brings about benefits such as achieving flexibility in operations, receiving diverse innovative ideas and also evoking empathy all around the organisation (Halle \& Wolfe, n.d.). She further stated that DM helps greatly in problem-solving as it helps to bring about more self-consciousness and competitiveness. However, other critics posit that despite these vaunted benefits from practising DM, it comes at greater cost to the firm or organisation. Also we have to bear in mind that there are variations to practising DM as the type of product, technology used and size of organisation all determine whether a firm should practise it or not (Al-Rodhan, 2006).

Fassinger (2008:253-254) in her work, concentrated on salary disparities at the workplace on gender basis as well as less participation of women in policy making. Women football players, BBC women journalists and women workers at Hollywood have all complained about being discriminated against in emoluments as their male counterparts earn far more than them. This issue shows how in the past the gentrification of workplaces or having male-dominated boards has led to the making of policies to favour men (Torrington et al., 2011; Weightman, 2004; Thomas \& Petersen, 2015; Fassinger, 2008). Thus, our societies have persistently held on to social, economic and political systems that perpetrate social, economic and political injustice (Coleman et al. 2014:56 -73).

These issues need to be tackled by engaging socio-economic and political systems at their tap roots to uproot all the perceived injustices by, for example, tackling gender imbalance in the workforce. Patrick \& Kumar (2012) in their work recommended creating positive 
environment for DM to thrive by having ergonomic or worker-centred environments where similarities and differences are accommodated and valued. However, this can sometimes lead to conflicts which are inevitable and unavoidable at the workplace.

Practising DM can reduce the intensity of conflicts and help employees see each other as part of one big family. Patrick \& Kumar (2012) in their monumental work surveyed 300 IT workers and the results showed that workers became more satisfied and more committed to the organisation where DM was practised and given prominence which led to improved organisational performance and higher bottom-line. Gilbert, Stead \& Ivancevich (1999) cited in Patrick \& Kumar (2012) pointed out that in their study of organisations, they had found out that high-ranking women in organisations had gained their positions on merit yet they were stigmatized as beneficiaries of Affirmative action, which demeaned their achievements on merit.

Patrick \& Kumar (2008) in their extensive work classified their respondents into DM optimists, DM pessimists and DM realists. The former believe DM is possible at their workplace while the pessimists do believe social justice cannot be achieved where there is no political justice of being treated equally as a citizen. The realists believe that life cannot be even and they accept the status quo ante as given and immutable.

Inegbedion et al. (2020) posit that the practice of DM helps to enhance and encourage teamwork which has been the hallmark of the Japanese since the 40s at Toyota and other Japanese companies. They contend that DM helps to generate inter-cultural communication and dialogue, thereby helping to resolve conflicts.

Sharma (2016:63-79) in contrast looks at DM broadly by asserting that changing demographics in the First World and changing global perceptions on ageing have brought the need to encourage child birth and import immigrants as means of resolving problems of labour shortage. According to Sharma (2016) practising DM is seen as an intelligent response to aligning with market trends and responding to demographic dynamics in an innovative way. While Sharma (2016) looked at the issue of DM spatially, Atiyah (2016) looked at DM as a method of preparing current labour force to be ready for future paradigm shifts in innovation, growth, and market share. Thus DM captures spatial needs as well as time-based needs.

Bassett-Jones (2005) in his article, referred to how the practice of DM poses as a paradox because on the one hand DM confers benefits in the form of creativity, flexibility and innovation, and on the other hand it creates conflicts and demotivation as it erodes competition, as we have to lower the standards to accommodate other people who are less capable. However, to the negativities posed by Bassett-Jones, we can rest assure him that using Edward de Bono's Six Hats of Understanding; we can always see the benefit derived from having a mix of people who see things in multi-dimensions. Howard Gardner also reminds us that we are all endowed with different intelligences which complement one another and are beneficial in solving a milieu of problems.

Urbancova et al. (2020) viewed DM as a way of gaining competitive advantage and having long-term sustainability in operations, with a view to aligning with the UN SDG goals. It can 
therefore be seen that the practice of Diversity Management can indeed help drive the first six Agendas of the UN SDGs. The SDGs address both sustainability goals for individuals as well as for organisations as they are holistic, complementary and interdependent. According to Urbancova et al. (2020), the thrust of DM is to reduce considerably all types of risks such as financial, human, technical and systemic risks.

Fassinger (2008:253) alluded to two Acts as supporting the practice of DM in the USA, namely, The Disabilities Act 1990 and the Employment Non-Discriminatory Act 2007. These two Acts empower employers in the USA to look after the interests of disadvantaged groups at the workplace and it should be set forth as a model for other countries to emulate. There is also the Employment Equal Opportunities Act of 1972 which makes it an offence to be discriminated against on the basis of gender, age, race, nationality, religion, colour and disability.

Fassinger (2008) believes that where DM is practised, it engenders thought-provocation and makes employees consider the plight of others, especially immigrant workers who go through cultural shock, different labour laws, and having to adjust to the weather in hostile climates (Starling, 2008).

Byars \& Rue (1997) affirmed that the changing dynamics of demographics in the USA showed that more women, migrants and other minorities were rapidly making inroads in the labour force through high or increased labour force participation rates, leading to the need to look at issues such as work flexibility, cultural sensitization training, and attending to welfare issues of creating crèches for women with young children, maternity leave, equal pay for equal work, creating equal opportunities, strongly opposing sexual harassment at work, among other issues (House et al, 2004; House et al., 2002; Mondy, 2002). Byars \& Rue (1997) further noted that the presence of immigrants in the labour force would force HRM to design special training programmes for handling immigrants' needs such as language difficulties and also need to help their families settle down and be fully integrated into their new cultural environments, in order to reduce cultural shock.

Table 4. Labour Dynamics due to Demographic Changes

\begin{tabular}{|c|c|c|c|}
\hline Race & $\mathbf{1 9 9 2}$ & $\mathbf{2 0 0 5}$ & $\mathbf{2 0 1 7}$ \\
\hline White & 77.8 & 72.9 & 78 \\
\hline Black & 10.8 & 11 & 13 \\
\hline Hispanic & 8 & 11 & - \\
\hline Asians & 3.4 & 5 & 1 \\
\hline Amerindians & 1 & 1 & 6 \\
\hline
\end{tabular}

Source. Adapted from US Bureau of Labour Statistics 2017

Table 5. Gender Shifts in Labour Composition

\begin{tabular}{|c|c|c|}
\hline Gender & $\mathbf{1 9 9 2}$ & $\mathbf{2 0 0 5}$ \\
\hline Male & 54.5 & 52.3 \\
\hline Female & 45.5 & 47.7 \\
\hline
\end{tabular}


Source: Adapted from Byar \& Rue 1997 pp. 253

\section{Discussion}

Table 4 and Table 5 above show trends in the labour force in the USA showing its composition by race and also by gender. It is quite clear that the participation rates of women and people of colour have been increasing, thereby pointing to the need to reform Human Resource practices around the world to take stock of the demographic shifts. The authors of this article take the stance that rapid developments in industry and pressure from the international community can force organisations willy-nilly to adopt the practice of universal inclusion and diversity management as depicted in our conceptual model in Figure 4 above. The subsequent discussion of two case studies and practices in industry and educational establishments show that diversity management has come to stay with us and it is part of the demographic paradigm shift.

\subsection{Discussion of Two Case Studies}

The first TED-EX video in our discussion shows Michael Gavin delivering a lecture at Syracuse University in New York. His approach is ethnographical, anthropological, philosophical, anecdotal, analogical and a lot of evidence of philology and linguistics. Michael should be someone with training in linguistics as his presentation tells us that there are about 7000 languages in the world and in say 50 years from now, half of them will be extinct due to cultural imperialism and mental colonization of the world by a few powerful social or ethnic groups. He avers that in that event, it would be a colossal calamity to mankind as a lot of local lore and knowledge would have been lost forever, hence efforts by UNESCO and other institutions driving efforts to preserve endangered languages.

The sad case of David from the South Pacific Vanautu community who passed away with the knowledge of his native language, which was spoken by him and two remaining old people, shows us how the cultural diversity pot is getting depleted fast, leading to a homogeneous and culturally-deficient world, where knowledge of ethnic lore, mores, norms and native knowledge would be lost for ever. Michael states that culture is dynamic and evolving because of acculturation, cross-cultural fertilisation and cultural diffusion. Michael informs us that cultural diversity helps us to utilize knowledge and skills from anyone and everyone in the world without prejudice, thus we should celebrate our individual identities, differences, nuances and idiosyncrasies, and otherliness in the cultural tapestry, panoply, panorama and kaleidoscope.

There is unity in diversity and also synergy in being different in order to view problems from different cultural perspectives. Each culture brings something to the global arena for discussion. That is the crust and gist of Michael's message. It is known that in-breeding dilutes the blood of the in-breeders and they become less resistant to diseases. Thus, practising diversity by marrying from outside the family circle helps us to prolong and sustain our progeny. Michael states that we live in a complex and uncertain world so diversity management helps us have the knowledge to meet those future complexities and uncertainties with collective strength. 
During the Second World War, Native Americans were deployed as Code-Breakers because their native languages were used to send messages in order to defy the enemy. Such is the beauty of America having people from all over the world with each having something special to offer. The British similarly used the Ghurkhas from Nepal to fight in mountainous areas and Africans from West, East, South-Central, and South Africa to fight in the jungles of South-East Asia. In the UK, most tunnels and underground sewer systems were built using labour from Ireland and the West Indies. In Zambia, the Lozi people from Western Province of Zambia are the preferred labour on the sugar cane plantations in Nakambala estates in Mazabuka District in the Southern Province of Zambia.

Embracing cultural diversity helps us to realize our place in making the world a better place through our contribution. Cultural diversity, according to Michael, helps us deepen our knowledge of other people, to develop interrelationships, and a deeper appreciation of other people, and to reduce our cynicism, our biases, and to remove ambivalence or what Festinger calls cognitive dissonance whereby we hold two contrasting views over a matter due to internal self-crisis. Embracing cultural diversity enables us to be humble and to overcome our superiority and inferiority complexes, our narcissist tendencies, our fears or phobias of other people, our neuroses, and to reframe and adjust our culturally-tainted lenses.

Michael further gives us the analogy of quinine which came from the cinchona tree in Peru which helped to cure malaria. (Alphonse Lavaran from Belgium and Ronald Ross from Britain had earlier on in the 1950s collaborated to discover that the serum of female Anopheles Mosquito carried the malaria vector). There is an issue of intellectual property rights here as Imperial Chemical Industries (ICI) in the UK and Pfizer/GlaxoSmithCline Companies may not have paid the locals for their local knowledge. However, the fact remains that due to cultural diversity, those locals gave the world the cure for malaria. Now Artimisenin from Chinese herbal medicine is the cure for malaria. Thus, the Chinese have also given us knowledge due to cultural diversity. This shows us that knowledge is not the exclusive preserve of any one ethnic group as statistically, knowledge is fairly and evenly distributed along the Gaussian Curve or bell-shaped curve of error.

Had America not had Albert Einstein, a German-Jew from Switzerland, and other German immigrants who sold the atom bomb idea to Roosevelt, the Second World War would not have gone the way of the Allied forces but rather that of the Axis powers of Germany, Italy, and Japan. The native woman in the Amazon in Peru asking Michael whether the moon shone also in America indicated that we are very different in physical appearance and separated by long geographical distances and barriers yet we are united by many commonalities and access to global commons such as the oceans and heavenly bodies which none of us owns. This speaks volumes to us as human beings to realise our interdependencies and our need for mutual co-existence.

This enjoins us to work in concert for a sustainable world and to let go our parochial and selfish agendas by cooperating with the UN system in maintaining world peace and supporting the objectives of the 17 Sustainable Development Goals set for 2030. The native woman asking about Monica Lewinsky showed that the world has indeed become a global 
village due to ICT and as such we should embrace all people as one and treat people equally by giving everyone equal opportunities. We should reduce the imbalance of power in our countries and also among nations so that we enjoy distributive and affirmative justice, social and political justice, rather than retributive and ascription-based justice. We are having less biodiversity in the world because of the greed of a few selfish tycoons who endanger the livelihoods of poor natives whose lands are grabbed for mining concessions, plantations, and real estate development, among others.

Michael infers in the video that the actions of few powerful selfish individuals has led to cultural imprisonment of knowledge in some native communities whose lives are dictated to by policies crafted from powerful people somewhere in London, Brussels, Washington, Madrid, Berlin, Moscow, or Beijing. The world is going towards a one language, one educational curriculum, and a monolithic government system. This is dangerously dangerous according to Michael Gavin. He advises that we should be proud of our language and culture, to preserve it for posterity and for contributing it to global diversity. He is echoing what UNESCO does in preserving world heritage. He advises us to learn to use our knowledge base to promote the frontiers of knowledge. He says we should create systems to embrace inclusivity, diversity, creativity, and innovation which emanate from celebration of our differences.

In the second video of our case studies, Donald Melville speaking in the TED-EX video at Colorado State University gives us the paradigms of diversity. He states that he is an amalgam, gestalt, and a composite of many racial and ethnic groups around the world as shown by his DNA analysis. In his video, he talks of four groups of students deployed to go and rake fallen leaves in an old age home and they all approached the task differently, showing that each group reacted to the problem or task based upon their personalities, attitudes, needs, perception of the problem, team norms, values, beliefs, among others. Each group interpreted the problem differently, based upon their experiences, expectations, and cultural backgrounds.

\subsection{Practical Means of Approaching Diversity Management}

Douglas (Melville, 2015) gives nine acrostics or acronym for dealing with the management of diversity at the workplace and everywhere, especially for those working in Multinational or Transnational Corporations at home or abroad who need emotional, cultural, and social intelligence to succeed (cf. Omedien et al, 2012; Schneider et al., 2013). Douglas's (Melville, 2015) acrostic is based on how to improve your Diversity IQ. He states that there are 100 million Millennials in the USA who need to master management of diversity to become future leaders. Douglas uses the first nine letters of the alphabet namely A, B, C, D, E, F, G, H, and I for his IQ Diversity paradigm.

A -being Aware of differences in people irrespective of age, gender, ethnicity, experience, sexual orientations, social class, religious persuasion, and political affiliation.

B - Be yourself by accepting yourself and not being ashamed of your origins or of not being accepted by others; have self-confidence that you have talent or unique gift to bring to the table 
C- Check for bias in your actions and in your relationship with other people as regards your conscious and unconscious bias

D- Take a DNA dive to know yourself and your origins by googling or searching online to know your genealogy (this writer recently took an online test on Facebook and was told he is part German and part Norwegian! How can he believe that when he is a black African?! And that the historical figure he resembles is Sir Isaac Newton! What flattery!)

Eat outside to taste many foods and cultures to help you loosen up and erase your bias towards other cultures

Focus on feminine issues such as glass ceiling, glass walls, gender equality, affirmative action, and equal pay for equal work

\section{GLAAD Pay attention and embrace Gays and Lesbians}

H Check your hidden handicap which heightens your complexes, anxiety, apprehensions and self -projection or not having internal locus of control. This issue does affect1 billion people worldwide.

Inspire and Insight- Gain insight to look at the bigger picture to become open-minded and to inspire others (Melville, 2015)

Michael Gavin's (2014) approach in the first video is extensive as it covers diverse issues and diverse disciplines as he uses a multi-disciplinary and overarching approach which is eclectic. On the other hand, Douglas Melville (2015) in the second video uses a humorous and practical approach which focuses on implementation while that of Michael dwells on ethical, moral, philosophical, linguistic, and epidemiological approaches. They both harp on the commonality of the diversity issue which has become topical and current because of the high levels of mobility in the world due to globalization, expansion of multinationals, and the information revolution. Besides, social media has bridged the digital divide, which has led to convergence of media platforms, and papered over the dichotomy of haves and have-nots as many Millennials who are technophiles, nettopreneurs, and technopreneurs are setting up virtual businesses and networks, and empowering themselves through being savvy, au-fait, innovative and working smart as computer geeks and nerds.

\section{Findings}

\subsection{Philosophical Look at Diversity Management}

Diversity on the one hand can be viewed in its raw state as an organised orgasm of a chaotic kaleidoscope of colours in their subtle hues, and on the other hand as an amalgam, a gestalt or a holistic gel or whole, whereby a mixture of different varieties of colours ends up in a pure delight of white colour, whose effulgent sheen dominates and subdues all the other colours taken individually and severally as stand-alone. The aphorism, Unity in Diversity, is germane in this sense as we agree to disagree and learn to live and be lived with. Diversity 


\section{Macrothink}

International Journal of Human Resource Studies

ISSN 2162-3058 2021, Vol. 11, No. 1

management therefore represents the acceptance of the fact that in a normal distribution in a very large population, we simulate the symmetrical looking Gaussian curve or normal curve of error whose distribution frequency and area under it adds up to 1 or 100 per cent.

\section{Stirling's Approximation for Calculating Area under the Normal Curve Distribution}

$$
n ! \approx \sqrt{\left(2 n+\frac{1}{3}\right) \pi} n^{n} e^{-n} .
$$

(Spiegel, 1975:11)

Source: https://mathworld.wolfram.com/StirlingsApproximation.html

The Moment Generating Function for Finding Area under the Normal Curve

$$
f_{g}(x)=\frac{1}{\sqrt{2 \pi \sigma^{2}}} e^{\frac{-(x-a)^{2}}{2 \sigma^{2}}}
$$

\section{Source: http://hyperphysics.phy-astr.gsu.edu/hbase/Math/gaufen.html}

Stirling's approximation is used to calculate the area under the normal curve by using calculus to integrate it from negative infinity to positive infinity or by using the Binomial distribution method whereby the area is $n$ !, and where $n$ is found to be very large such that using Stirling's approximation, the area approaches 1 or 100 per cent.

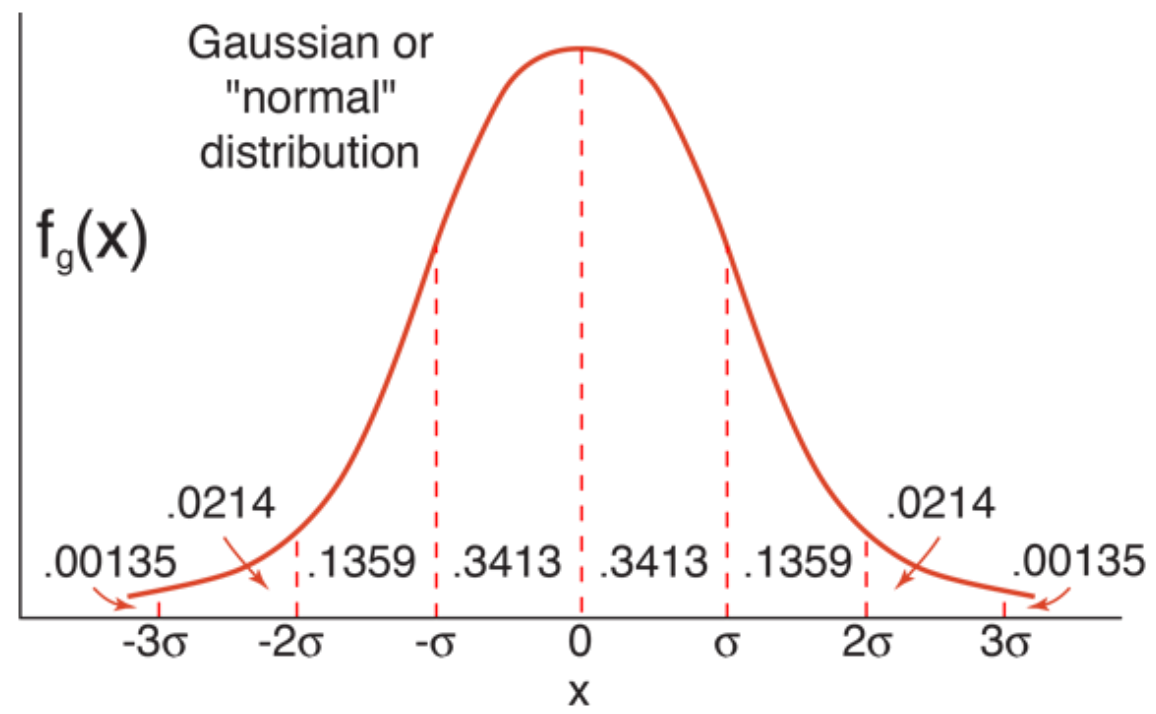

Figure 5. Gaussian or Normal Distribution Curve 
Source: http://hyperphysics.phy-astr.gsu.edu/hbase/Math/gaufcn.html

Thus humanity of different heights, sizes and hues can be perfectly arranged under this bell-shaped curve without leaving any small chink in between as seen in Figure 5 above. In this scenario, everybody matters and in the scheme of things, everyone is a valuable piece of the big tapestry of the human jigsaw puzzle.

Knowledge of the Normal Distribution curve and its characteristics help us understand the concept of Diversity Management better because it broadens our mind to accept individual differences and also open us up to be liberal-minded, tolerant, and above all, empathetic (Spiegel, 1975:11).

Those who recognise diversity and the need to manage it may subscribe to the principle of the commonality of humanity, and also the fact that all human beings are of one essence, manifesting individually on different frequencies and vibrations, and that we come into this world in different hues and sizes for the purpose of complementing one another. This is why most successful organisations use the Japanese teamwork principles of the Toyota Way, Kaizen, TQM, Quality Circles, JIT, and Lean Production 6 Sigma, among others (cf. Mullins, 2010; Robbins \& Judge, 2013)

We can also see that the management of diversity is hinged on the concept of synergy and the General Systems Theory of all parts of an entity being interdependent, differentiated but all working towards a common goal, and having in-built homeostatic or cybernetic control system for self-regulation (cf. Katz \& Kahn, von Betalanffy). We can liken diversity management to the constituent parts of Michael Porter's Value chain where the internal inflows and outflows have to be balanced. In the same way, the Supply pipe-line can be sustained only when all the sub-systems are working well to avoid supply bottlenecks and bullwhip effect (Johnson, Scholes \& Wittington, 2017).

If we form valuable partnerships and collaborations in the supply chain straddling many countries, we guarantee ourselves of sustainability of operations if we respect all people irrespective of their stations in life. We can be successful in diversity management if we adopt a win-win approach, making everyone a winner. In this way, we even ditch Stuart-Mills Utilitarian principle of the greatest good for the greatest number and adopt a new maxim of, 'To all, the best of all worlds. To none half measures nor half interest shown'.

Our political dispensation of democracy based on majoritarian principle has become dysfunctional in the sense that we often see a 'Winner-Takes -All' scenario which creates a lot of bitterness on the part of losing minority parties. We should rather build all-inclusive systems which allow losers to have closure, breathing space, and certain in-built automatic rights and privileges to control certain critical functions and portfolios, as compensatory statutory measures to ensure Montesquieu-like checks and balances.

More often than not, stereotyping and having closed minds lead us to distrust good intentions of Diversity Management as we become brainwashed and dogmatic in our steeped beliefs and cultures. It will require us to use our emotional, social, and cultural intelligence to accept to embrace all people and to treat them equally. We need to wean ourselves from our erroneous 
prejudices which have no logical foundations or from our stand-offish hubris and narcissist tendencies.

Table 6. Student Composition of some Selected Universities

\begin{tabular}{|c|c|c|c|c|c|c|c|}
\hline $\begin{array}{l}\text { Name of } \\
\text { Org }\end{array}$ & Male \% & Female\% & Nationals\% & Non-Nationals & $\begin{array}{l}\text { Total } \\
\text { UG } \\
\text { pop. }\end{array}$ & $\begin{array}{l}\text { Total } \\
\text { PG } \\
\text { pop. }\end{array}$ & $\begin{array}{l}\text { Total } \\
\text { Student } \\
\text { Pop. }\end{array}$ \\
\hline Oxford & $\mathrm{NA}$ & $\mathrm{NA}$ & $55 \%$ & $45 \%$ & $\begin{array}{l}11,955 \\
(50 \%)\end{array}$ & $\begin{array}{l}12,010 \\
(50 \%)\end{array}$ & 24,000 \\
\hline Cambridge & & & $\begin{array}{l}14,693 \\
(77 \%)\end{array}$ & $\begin{array}{l}4,454 \\
(23 \%)\end{array}$ & & & 19,197 \\
\hline Harvard & & & $\begin{array}{l}31,566 \\
(77 \%)\end{array}$ & $\begin{array}{l}7,274 \\
(23 \%)\end{array}$ & & & 38,840 \\
\hline UCLA & $40 \%$ & $60 \%$ & $90 \%$ & $10 \%$ & & & \\
\hline MIT & $\begin{array}{l}2,463 \\
\text { (54\%) } \\
\text { (UG) }\end{array}$ & $\begin{array}{l}2,139 \\
\text { (46\%) } \\
\text { (UG) }\end{array}$ & $\begin{array}{l}1,201 \\
(26 \%)\end{array}$ & $\begin{array}{l}3,411 \\
(74 \%)\end{array}$ & & & $\begin{array}{l}4,602 \\
\text { (UG) }\end{array}$ \\
\hline Columbia & $48 \%$ & $52 \%$ & & 17,145 & & & \\
\hline Yale & $\begin{array}{l}2,971 \\
(50 \%)\end{array}$ & $\begin{array}{l}2,993 \\
(50 \%)\end{array}$ & $\begin{array}{l}2,189 \\
(54 \%)\end{array}$ & $\begin{array}{l}2,775 \\
(46 \%)\end{array}$ & & & 5,964 \\
\hline Princeton & $50 \%$ & $50 \%$ & $(88 \%)$ & $(12 \%)$ & & & 5,267 \\
\hline
\end{tabular}

Source: DIVERSITY FACTS (Various online sites)

\subsection{Findings of Diversity Management in Some Top Universities in the USA and UK}

Table 6 above lists some of the top universities in the world, mostly in the UK and USA. We settled on these ones because they attract the cream of the best students from all corners of the world. We tried to examine the global representativeness and diversity of these elite universities. Of course, we are aware of the seeming impossibility of some groups in the world to get representation in these top universities which have robust and extremely competitive methods of student selection criteria as well as being high-fee paying and top of the range in terms of market perception. Each of these elite and top-notch universities has its own marketing sales strategy and its market niche. Besides, the courses and programmes on offer in each of these universities determine who steps forward to purchase them.

Most of these universities have their clients from South East Asia, Japan, and most of the OECD countries in the First World where Per Capita Income (PCI) is in the top notch. Because of the high fee structure and also their interest to preserve certain standards, they tend to target rich social classes and also comfortable working professional classes. In that instance, so many nations and groups in the poor countries are marginally represented in these great citadels of knowledge.

Is this circumstantial exclusion or accidental marginalisation based on the incident of one's birth and parentage? To address these weighty questions, ways should be found to help capable students from disadvantaged areas to be selected by a kind of lottery so that the marginalized groups in the world can be brought on board. Some of these great universities have started online open source-ware to make their programmes accessible to many 


\section{Macrothink}

International Journal of Human Resource Studies

ISSN 2162-3058

2021, Vol. 11, No. 1

disadvantaged groups around the globe. However, on-campus exposure and networking advantages cannot be substituted for by remote outreach resources which are offloaded online.

Issues of cost, access and background are some of the challenges which unrepresented groups face in having one of their members to be selected into any of these Ivy League and Russell Group universities. There are efforts being made by MIT and Harvard, among many of these elite universities, to make their courses and programmes affordable and accessible online to as many capable but financially-disadvantaged and adverse selection bias students as possible from the poor areas of the world. We, on our part as authors and lecturers, take delight in observing that even though none of us got into the portals of these universities, we have at least taught and mentored many of our students to be admitted into the portals of some of these revered universities such as Harvard, MIT, Brown, Dartmouth, Cambridge, University of Pennsylvania, and Oxford, among many others.

\subsection{Diversity Management in Selected Universities}

We observed from the literature that some of the elite and Ivy League universities in the UK and USA adopt different Diversity Management approaches with some focusing on domestic or intra-country diversity while others focus on cross-cultural internationalisation or having a microcosm of the world on their campuses. Oxford and Harvard, for instance, tend to have more foreign post-graduate students than locals as they pursue cross-border or cross-cultural diversity while UCLA and Cambridge place emphasis on domestic diversity or intra-country diversity in their undergraduate programmes.

\section{Diversity Management at Princeton University}

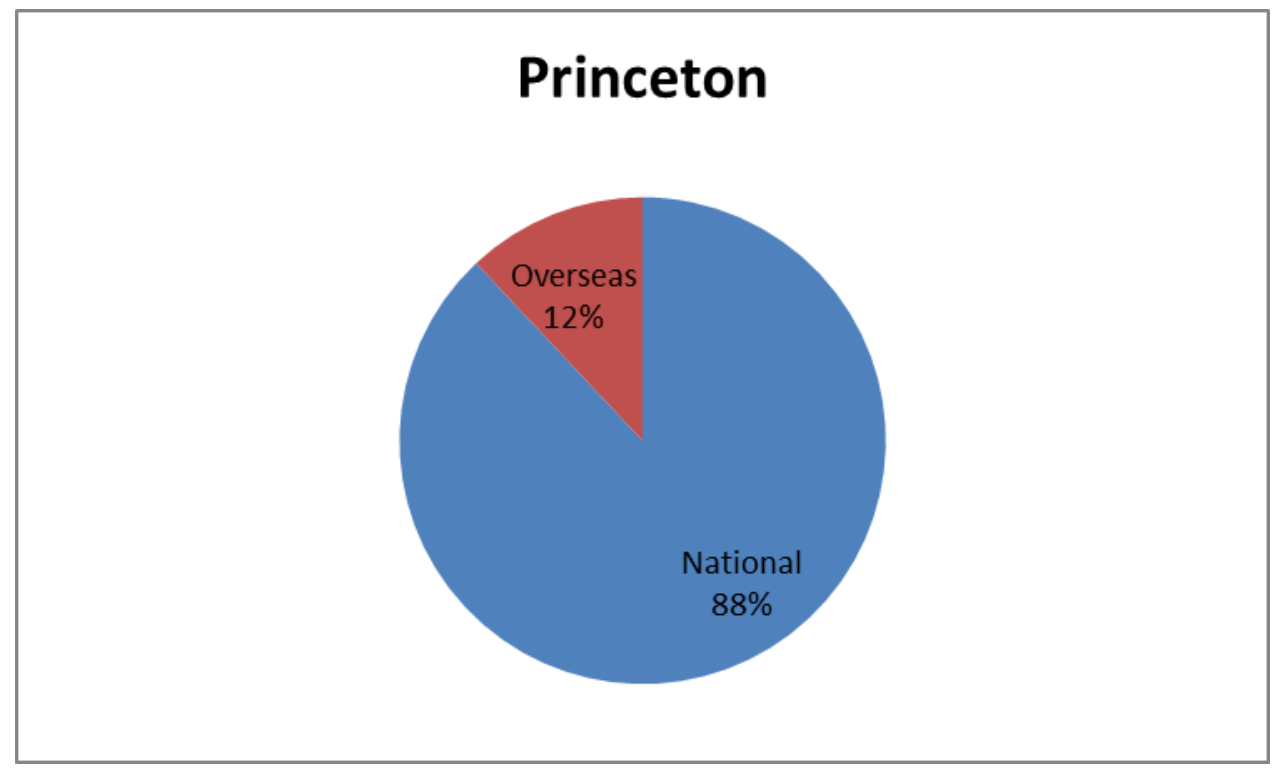

Figure 6

Princeton, where Albert Einstein lived and worked, boasts of 27 Nobel Laureates out of whom 18 are alumni. They have 76 per cent permanent or tenured professional faculty out of the total 


\section{Macrothink}

International Journal of Human Resource Studies

ISSN 2162-3058

2021, Vol. 11, No. 1

faculty of 1,289 members, with the remainder being part-time or Visiting overseas professors. They have 5,267 undergraduates and 2,946 post-graduates (Princeton University, 2020). In total, there are 643 undergraduate international students who constitute about 8 per cent of the entire student population. Princeton has 50 per cent undergraduate representation of women which is highly commendable. Princeton alumni are found in 155 countries around the globe. Of their 42 doctoral programmes, 33 are interdisciplinary doctoral programmes. The Institute for Advanced Studies (IAS) at Princeton has distinguished professors from all around the world participating in joint advanced multidisciplinary research in various fields of study (Princeton University, 2020). Princeton indeed epitomises a global microcosm of joint human endeavour to help solve some of the myriad problems the world is facing such as developing a vaccine to combat COVID-19. This endeavour to develop vaccines against COVID-19 is going on at Oxford, Harvard, MIT, Cambridge, and indeed in many of the top universities with excellent research facilities and top-notch scientists.

\subsubsection{Diversity Management at Oxford}

Oxford has a total student population of 24,000 with 11,955 being undergraduates and 12,010 being post-graduate students, a 50/50 balanced scenario. 64 per cent of graduate students come from outside the UK. Each year, Oxford spends about 7 million pounds on its outreach programme to expose their course offerings to potential students in the high schools throughout the UK, and a further 8 million pounds to offer financial support to capable students who are financially-handicapped, among the Black African and Caribbean UK resident students (University of Oxford, 2020). International students make up 45 per cent (10,800 students) of the entire student population, one of the highest concentrations of foreign students in the world, behind Columbia University in New York, USA. Students at Oxford come from 160 countries with majority of them from USA, China, Germany, Canada, Hong Kong, Australia, Singapore, India, Italy, Greece and Switzerland, making Oxford one of the most diversified universities in the world (University of Oxford, 2020).

\section{Diversity at Cambridge}

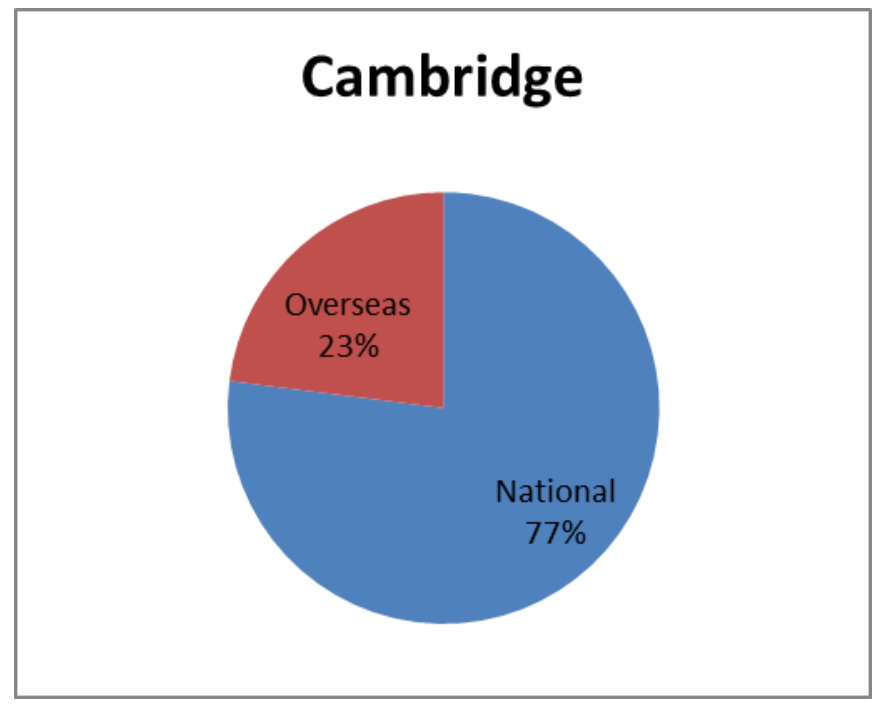


Figure 7

Cambridge has 2,463 male and 2,139 female undergraduate students. Of the total student population of 19,147 , there are 4,454 foreign students representing 23 per cent of the entire student population. Cambridge has 10,571 domestic undergraduates and 1,698 foreign undergraduate students. Oxford in contrast shows more international diversity than Cambridge (University of Cambridge, 2019). However, it could be said that Cambridge practises globalocalisation as they have their sights set on achieving domestic diversity as well as achieving some aspect of international diversity.

\subsubsection{Diversity Management at Harvard}

Harvard in all respects is a centre of excellence and a melting pot of different cultures from around the world. The advanced medical and public health programmes at Harvard draw many scholars, researchers and academia from all parts of the world to it to partner with their American counterparts to drive the frontiers of knowledge. Harvard is nationally ranked highly for her diversity management. There are 7,274 international students at Harvard representing $23 \%$ of the entire student population of 31,566 . There are about 50 nationalities represented at Harvard with majority of the international students originating from China, Canada, and India (DIVERSITY FACTS, 2020/Harvard).

\subsubsection{Diversity Management at MIT}

MIT is ranked $7^{\text {th }}$ nationally for her diversity programme. MIT has 2,463 male and 2,139 female students in their undergraduate programme which shows gender balance. It has 3,411 international students who come from 49 countries. Students in the age group 18 to 21 years constitute 36.3 per cent of the student population. Because of its high profile as the hub of cutting-edge technology, MIT attracts some of the best science students in the world, hence its diversity (DIVERSITY FACTS, 2020/MIT). MIT has 54 per cent males and 46 per cent females in their undergraduate programmes and this is not unexpected as MIT pursues many science and engineering programmes which female students lag behind in. This gender gap needs bridging in all parts of the world by assisting more females to take to STEM subjects of Science, Technology, Engineering, and Mathematics. It is encouraging to note that the UN, EU and AU have made it mandatory for institutions and organisations to take measures to bridge the gender gap in the not too distant future.

\subsubsection{Diversity Management at Columbia}

Columbia University in New York is really the centre of the universe as in 2019 it had 17,145 foreign students of whom 4,833 were post-graduate students. Columbia has foreign students who come from 156 countries (DIVERSITY FACTS, 2020/Columbia). Of its undergraduates, 52 per cent are female and 48 per cent male. Majority of the overseas students come from China, India, South Korea, Canada, France, UK, Brazil, Germany, Singapore, and Taiwan. Columbia has 3,159 foreign faculty members from 107 countries of whom 56.5 per cent are male and 43.5 per cent female. Columbia University really epitomizes diversity in both the diversity of its student population and the composition of its faculty which should be emulated by other universities (DIVERSITY FACTS, 2020/Columbia). 


\section{Diversity Management at UCLA}

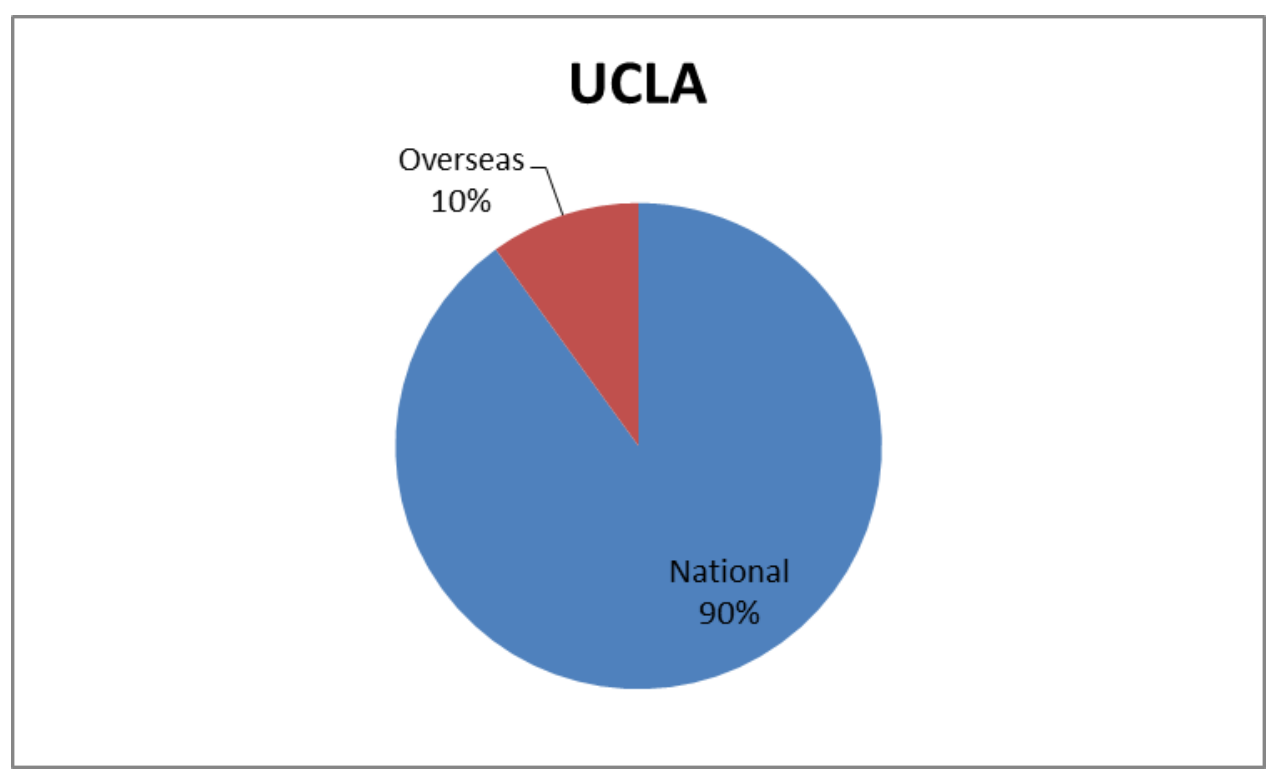

Figure 8

University of California in Los Angeles (UCLA) focuses more on achieving domestic diversity than attracting foreign students. Its freshmen have 40 per cent males and 60 per cent females. Of that number, 90 per cent are domestic students while 10 per cent are overseas students (UCLA, 2019). Of the domestic or local students, 30 per cent are of Asian origin, 20 per cent Hispanic, 26 per cent White, 6 per cent are people of two or more races, 1 per cent American Indian, and another 1 per cent Pacific Islander. Blacks are under-represented and that trend can be found in many universities in the USA which many authorities are trying to turn around due to pressure from the Black Lives Matter Movement (UCLA, 2019).

\section{Diversity Management at Yale}

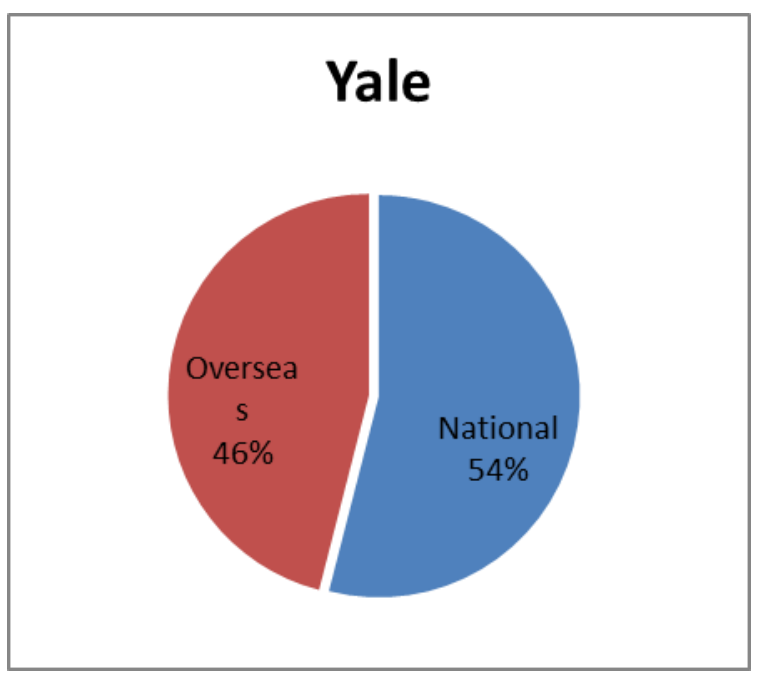

Figure 9 


\section{Diversity Management -Gender}

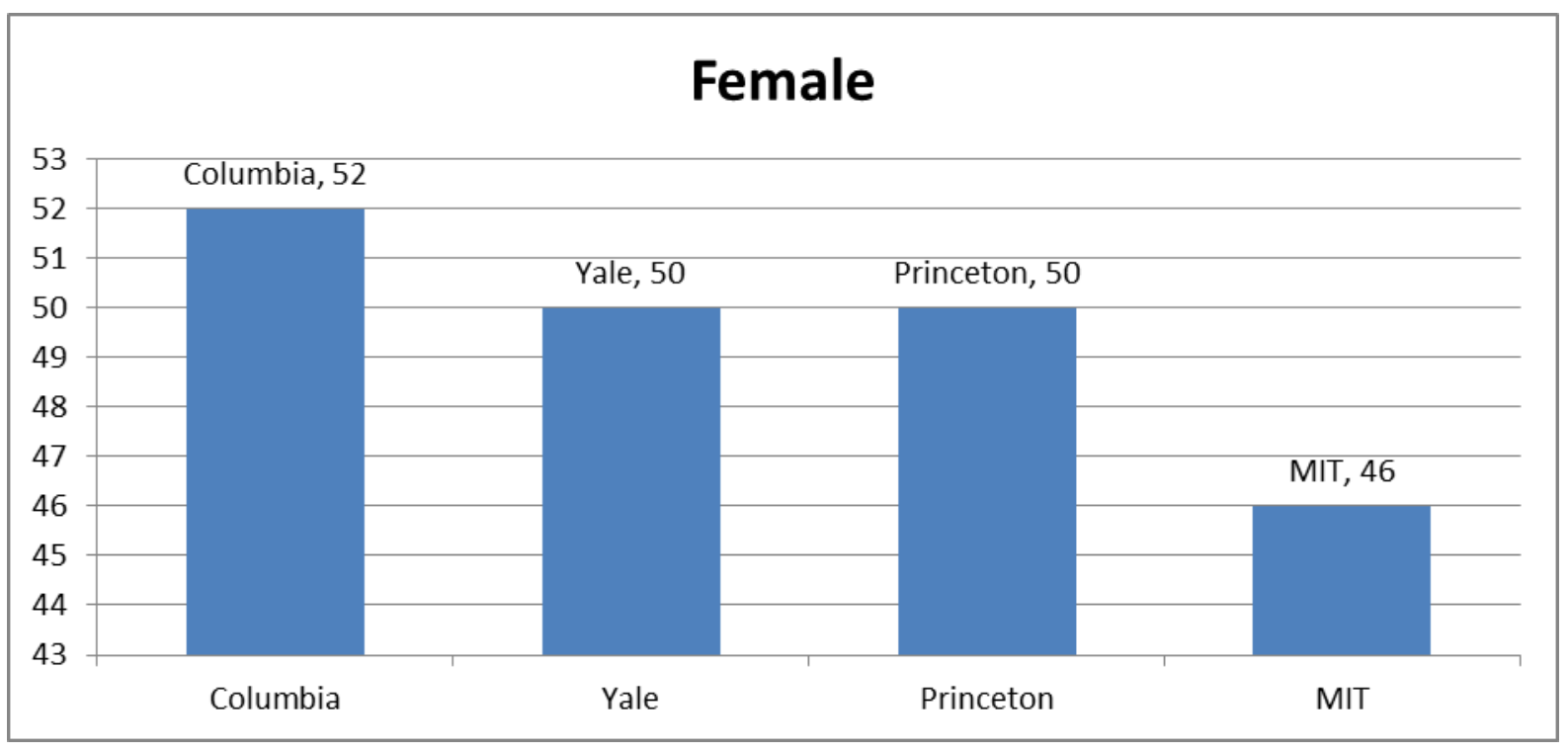

Figure 10

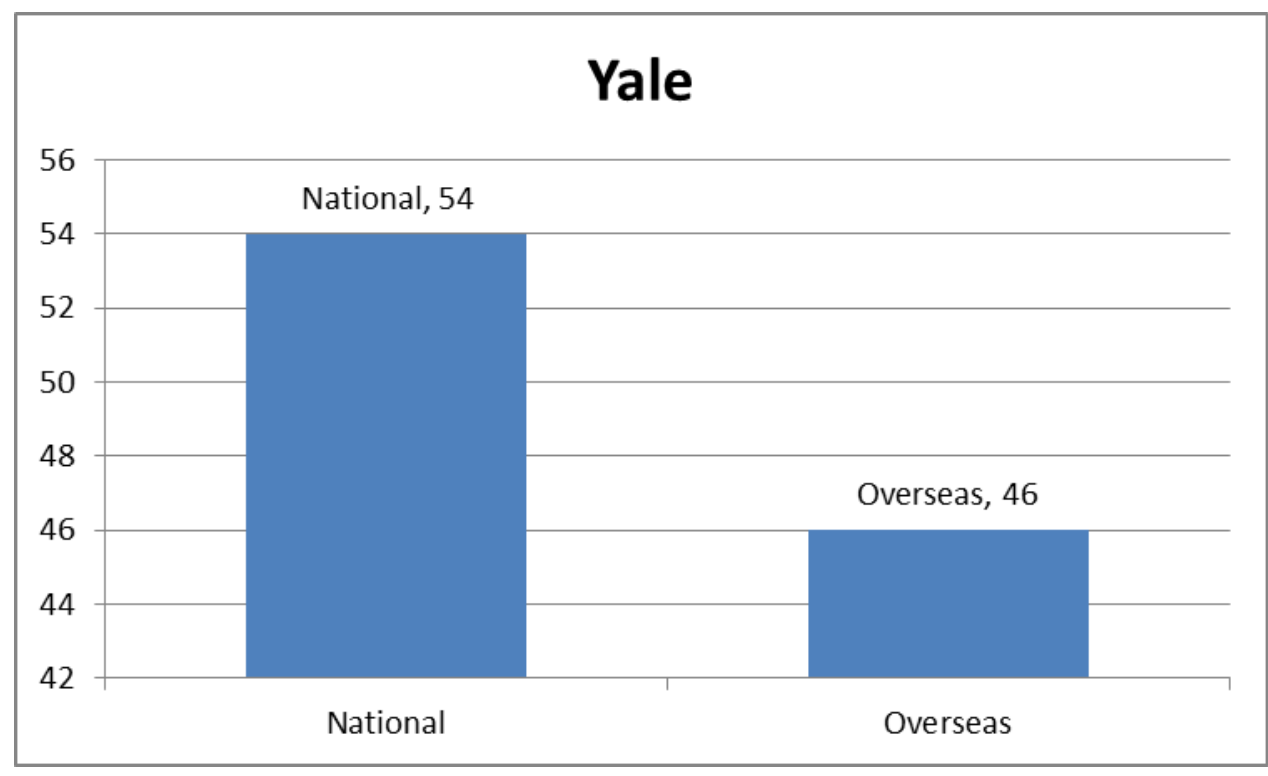

Figure 11 


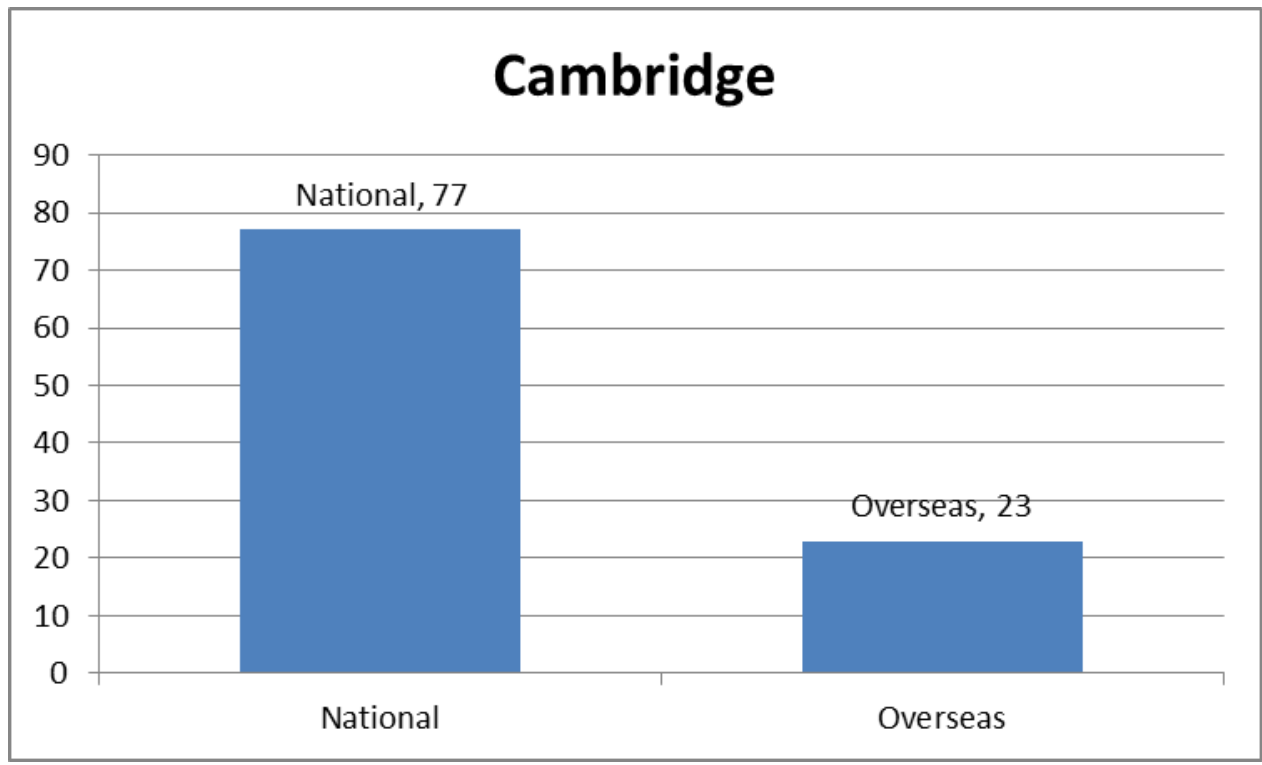

Figure 12

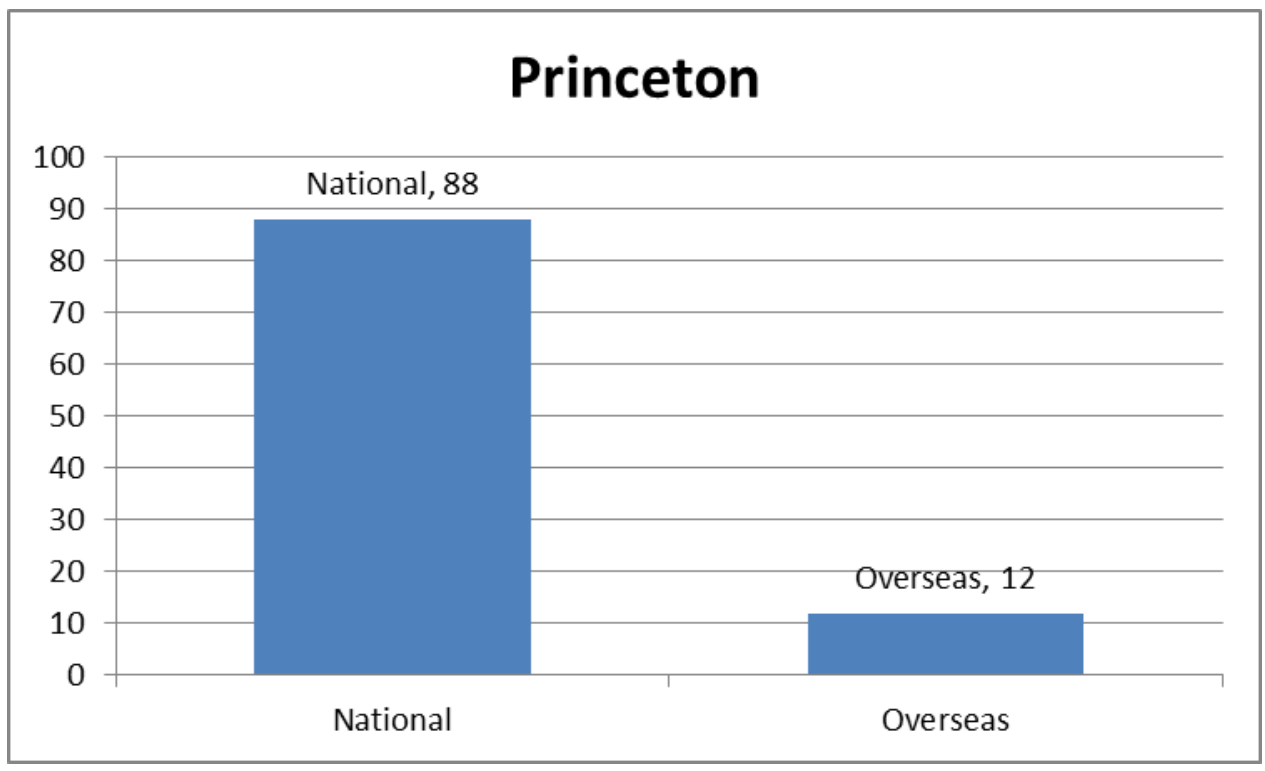

Figure 13 


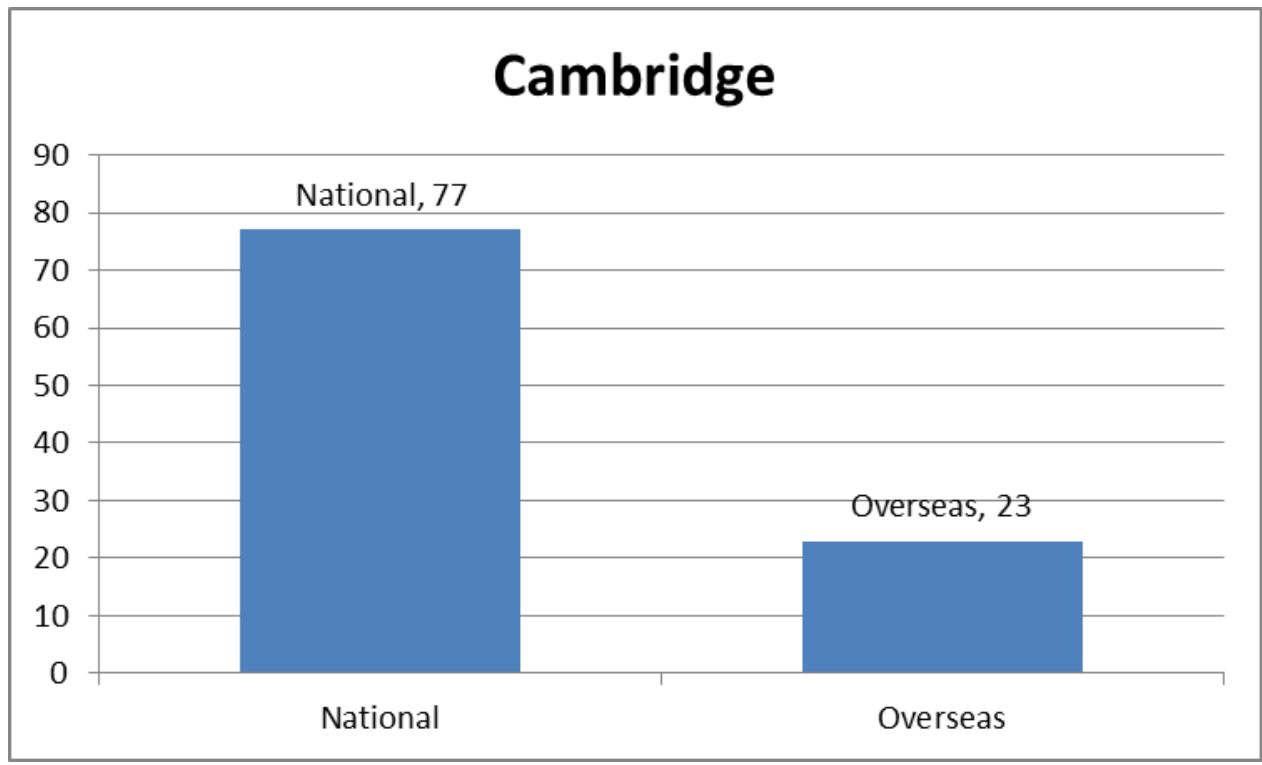

Figure 14

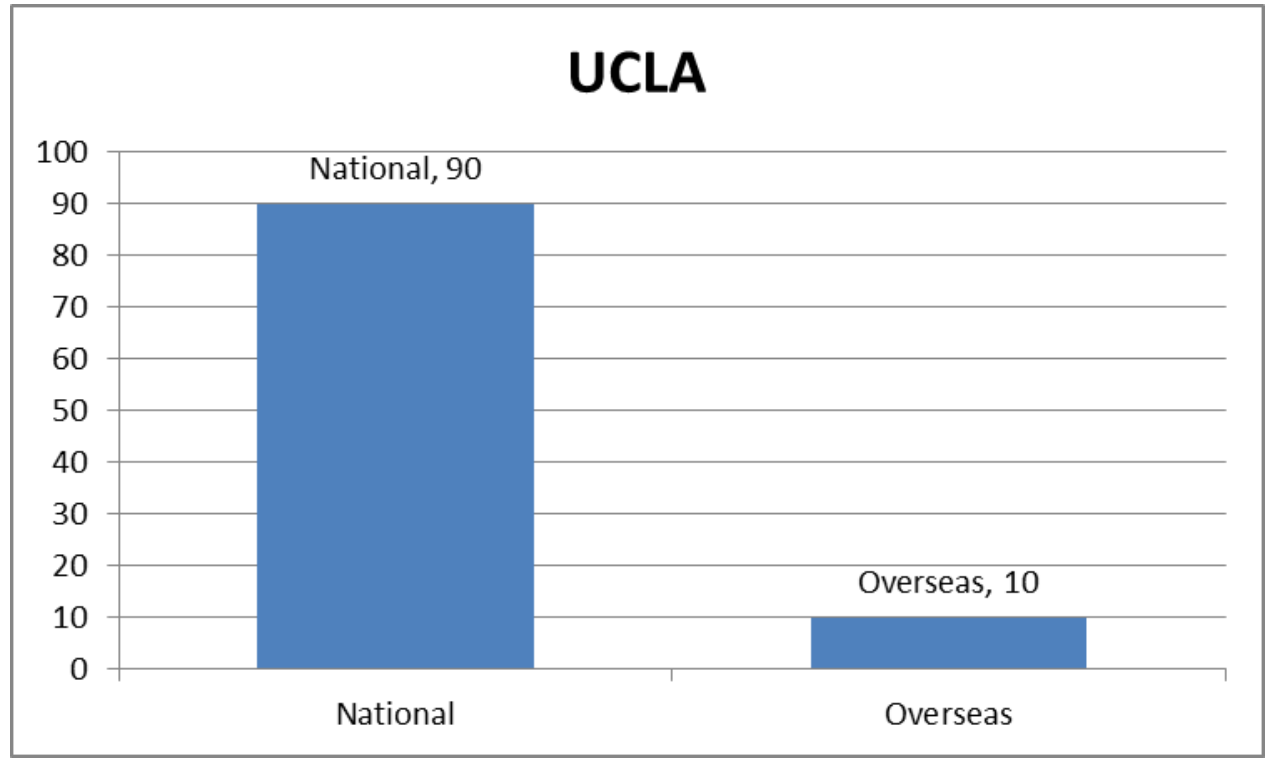

Figure 15 


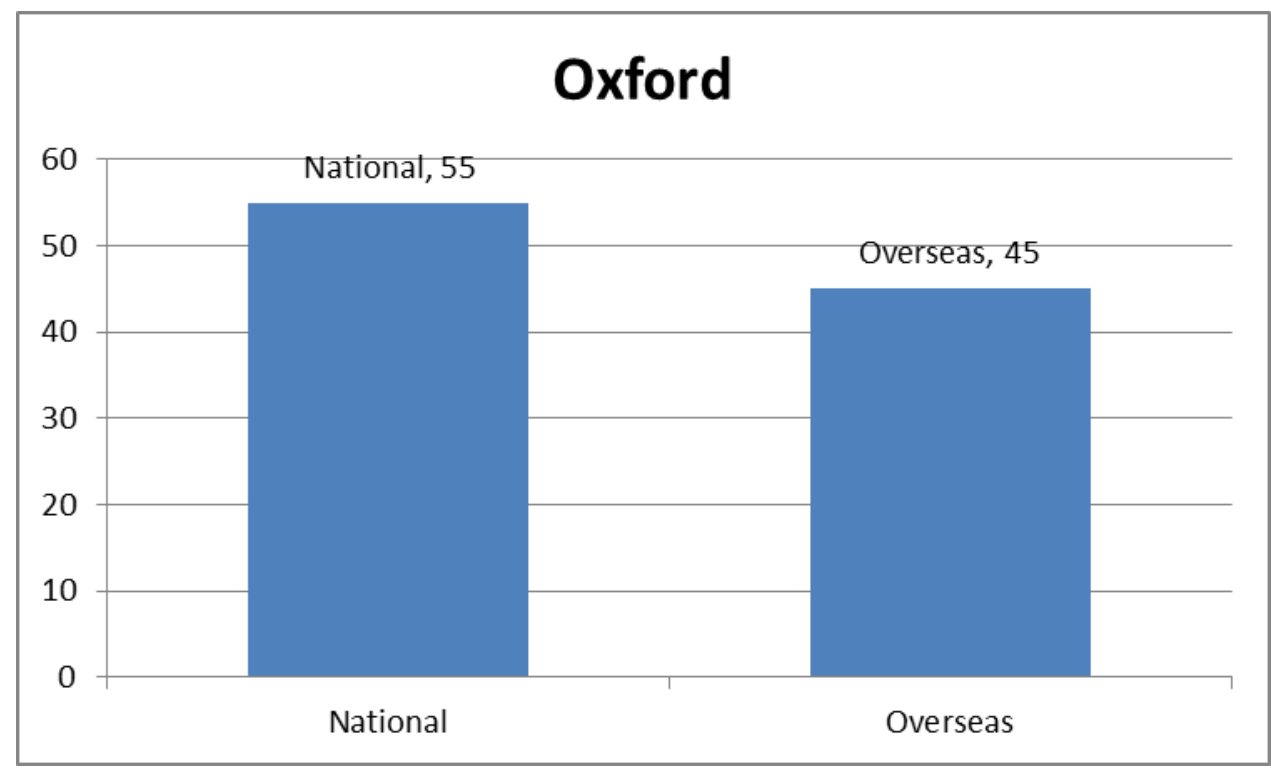

Figure 16

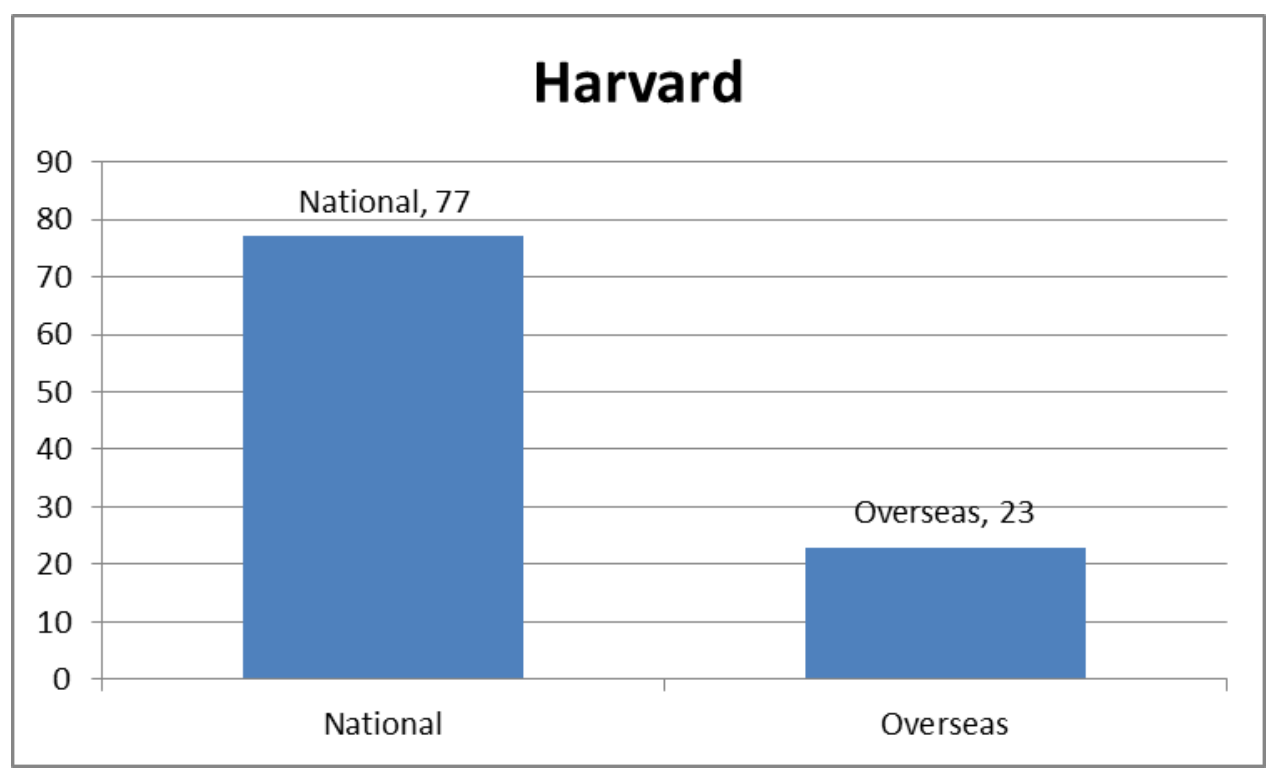

Figure 17

Yale University is one of the Ivy League universities in the USA which is famous for its Law programme just as Harvard is famous for Business, Management, Public Health and International Relations. The undergraduate student population at Yale is composed of 46.2 per cent White, 17.3 per cent Asian, 12.2 per cent Hispanic, and 11 per cent overseas students (DIVERSITY FACTS, 2020/Yale). Again, Blacks are not adequately represented in this elite university. This anomaly could be due to the high fees charged which is beyond the means of many Black families. The faculty at Yale is multicultural, made up of 62.8 white, 11.2 Black and 8 per cent foreign hire or overseas professors. Yale has 2,775 foreign students from 48 countries. The undergraduate student population at Yale consists of 2,971 males and 2,993 females, showing a gender balance (DIVERSITY FACTS, 2020/Yale). 
According to Buckingham \& Vosburgh cited in Armstrong \& Taylor (2014:18) talent is embedded in everyone and so it is important to help employees, irrespective of who they are, to reach their full potential. Thus diversity should be linked to talent management. Kamoche (2001:100) asserted that a multicultural labour force will enrich talent and help multinationals succeed greatly abroad by having managers who are well prepared for their assignments, irrespective of whichever recruitment model or strategy is used, be it ethnocentric, geocentric, regio-centric or polycentric (cf. Perlmutter, 1969).

Kamoche (supra) further stated that diversity approach will enable managers develop global mentality to think global but act local (globalocalization) by adapting easily to any environment as smoothly as a duck takes to water. He stated that diversity management awareness will help MNCs develop long term International Human Resource Strategic Management Planning orientation by making every manager aware of ensuring that top management positions should not be filled by majority of Protestant/Christian male members but by people from all walks of life to show inclusiveness, acceptance, global representation, and also tolerance for all groups of people. Mullins (2010:151-162, passim) stated that diversity is recognising individual differences instead of treating people as homogeneous.

Mullins (2010) states that diversity is about having a plethora of differences among people and focusing more on individuality of people instead of on minority and marginalised disadvantaged groups. Mullins (supra) is of the opinion that focusing on disadvantaged groups through affirmative action, positive or reverse discrimination, among others is mere compliance with the law and playing to the gallery instead of dealing with reality at hand.

Mullins (supra) inferred that a diversity inclusive approach will eliminate the need to engage in a multiplicity of compliances such as enforcing gender equality, affirmative action, and reverse discrimination, among others. For an organisation that wants to stay ahead of the curve, it must spend a lot of time and resources by engaging experts to review all the legally-required compliances and with the help of HRM managers, formulate comprehensive Diversity Management policy document as a guideline. We strongly agree with this school of thought and think that DM is a multi-pronged approach that bestows many benefits on the firm or organisation. The DM approach resonates with the UN 17 SDGs and other objectives of multilateral organisations such as the EU, AU and OECD.

Mullins (2010:154) went further to state that being mindful of diversity management improves performance substantially as it improves loyalty of staff and clientele, and it promotes industrial harmony. It is also a good public relations stunt as it improves employment relations. It helps the company gain competitive edge over rivals and it helps it build internal capacity and capability for meeting supply chain shocks; it helps to make smooth engagement in the supply chain. It increases labour and operational flexibility and quick turnaround of business transactions both in the value and supply chains by reducing information asymmetry; external transactions cost, and it helps to avoid a situation of incomplete contracts due to psychological and mental blockages from misperceptions and biases. Diversity Management however, may vary in intensity, content, form and manner from place to place and from organisation to organisation, depending upon their peculiar 
circumstances.

Table 7 below shows some of the large multinational corporations in the world and their own aspect of DM. The reader is able to judge for themselves the diversity and representativeness of each of these global conglomerates. Many MNCs and top universities these days brag about their diversity practices in their adverts found on websites and other social media. Such adverts go like this:

'We are an Equal Opportunity Employer and we encourage women, people of different sexual orientations, people of disparate political, religious, and social dogmas, people of colour-all manner of minorities, to apply'.

Or like this:

'At XYZ Company, we are a large family sharing a common vision. We believe in family values, work-life balance, and life-long learning. We realize there is only one Earth and so we should be conscious and judicious how we exploit and use finite natural resources for a better tomorrow. We invest in biodiversity, multiculturalism, and cultivating high ethical values by cherishing our intellectual capital as well as creating value for all stakeholders. We believe in our common humanity, our interdependent world, and the need for sustainable lifestyles to save our planet from extinction'.

This goes to show how diversity has become a hot selling point for most leading organisations around the world.

Table 7. Diversity Management in Selected MNCs

\begin{tabular}{|c|l|}
\hline MNC & DIVERSITY PRACTICES \\
\hline 1. Toyota & $\begin{array}{l}\text { In 2020, Toyota had 359,542 employees both } \\
\text { in Japan and overseas, showing the vastness } \\
\text { of their operations in comparison to industry } \\
\text { giants such as VW, GM, Renault-Nissan, and } \\
\text { Ford. Toyota's key selling point over decades } \\
\text { has been safety of employees, efficiency and } \\
\text { customer-centric and diverse products to } \\
\text { satisfy variety of customers (DIVERSITY } \\
\text { FACTS, 2020/Toyota). }\end{array}$ \\
\hline 2. Coca Cola & $\begin{array}{l}\text { The focus of Coca Cola's corporate diversity } \\
\text { programme has been towards helping the } \\
\text { LGBTQ communities to be assisted with jobs } \\
\text { and empowered with skills through inclusive } \\
\text { and non-discriminatory practices such as } \\
\text { access to medical and health insurance } \\
\text { (DIVERSITY FACTS, 2019/.Coca Cola) }\end{array}$ \\
\hline 3. Hollywood & $\begin{array}{l}\text { Hollywood 2020 Report (Film) by UCLA } \\
\text { came up with the following statistics which } \\
\text { show that attempts at diversifying have }\end{array}$ \\
\hline
\end{tabular}




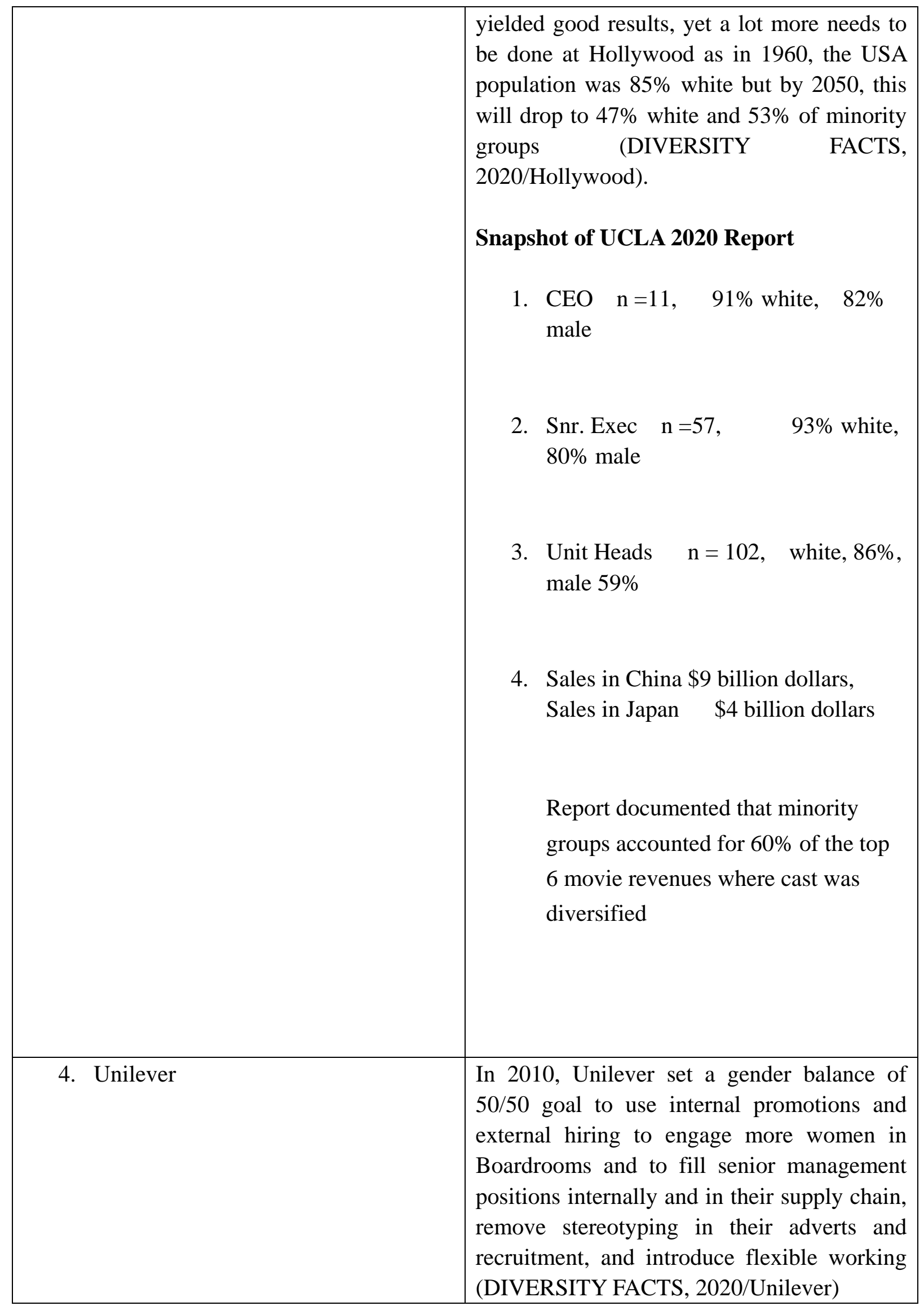




\section{Source: Several online sources}

\subsubsection{Some Case Studies of Diversity Management in Industry}

Coca Cola beverage is the most popular brand in the world according to DIVERSITY FACTS (2020). It is run from its headquarters in Atlanta, Georgia. Because of its huge global presence and huge sales, it has to play a leadership role in diversity management in managing sales of its diverse beverage drinks which reach every nook and cranny of the globe. Recently in 2019, its sales revenue reached 40 billion dollars with one third of its sales generated in North America where Coca Cola controls 50 per cent of the market and Pepsi controls 25\% (DIVERSITY FACTS, 2019; Statista, 2020/Coca Cola). Coca Cola spends 4 billion dollars annually on adverts alone. Coca Cola celebrates Diversity, Inclusion and Equality, with its focus on improving the cause of LGBTQ communities. It protects employees from sexual and gender discrimination by supporting the Employment Non-Discrimination Act 2007 (Statista, 2020/Coca Cola).

For seven decades now, the Toyota Car Manufacturing Company based in Toyota, Aichi in Japan has developed many business models which are well known throughout the world (DIVERSITY FACTS, 2020/Toyota; Statista, 2020/Toyota). The success of this leading world class company can be attributed to its people-employee-customer-centred policies as well as its readiness to embrace change, achieve perfection in its value chain, and deliver quality assurance to their esteemed customers at affordable prices. Toyota encourages engagement of all stakeholders, and believes in seeking continuous improvement with ideas coming up bottom-up from their lean and flat organisational structures.

Toyota is a learning organisation that rides on the back of its weaknesses to turn them around into strengths through tapping into their diverse labour force from around the globe (cf. Peter Senge). They run an open-door policy of transparency and they are very quick to accept their faults and restore their customers to their best convenience. Embracing diversity had been hard for Toyota but they have embraced change and decentralised most of their global operations to allow for flexibility and rapid response to customer needs (DIVERSITY FACTS, 2020/Toyota).

The Anglo-Dutch company Unilever (formerly known as Lever Brothers and United African Company (UAC)) has had a long history of being a leader in cutting-edge best industrial practices with their focal point being people-centred and research-biased in terms of developing new and safe products such as daily household goods, beauty care products, and detergents. The focus of Unilever's diversity programme is that of achieving 50/50 gender balance in their top management positions globally and also attracting and retaining top talent from around the world that can be assisted to unlock their full potential. Unilever aims to eradicate unconscious bias, stereotyping and gender discrimination in recruitment, and also to adopt flexible working methods to add value to their diverse operations (DIVERSITY FACTS, 2020/Unilever).

Unlike Unilever which has won universal acclaim and applause for her exemplary and forward-looking policies, Hollywood, in contrast as an institution, has been bedevilled and 
riled by many controversies and scandals bordering on damning issues such as sexual harassment, abuse and exploitation of women, issues of gender under-representation and minority marginalization, issues of unconscious bias, issues of gentrification of opportunities and erection of glass ceilings and glass walls, racial barriers, and baring women from reaching their full potential by shutting the door on their faces where career prospects are concerned (DIVERSITY FACTS, 2020/Hollywood; UCLA, 2020/Hollywood Report).

Until recently, Hollywood has been typified as an institution laden with masochism, misogyny and misanthropy, and more especially with discrimination against people of colour and of non-Caucasian origin. The Diversity Report 2020 (UCLA, 2020) entitled A Tale of Two Hollywoods makes interesting reading as it catalogues how women of colour were under-represented both in front and behind the camera in film production at Hollywood. This was in spite of the fact that movies by people of colour grossed majority of the Box Office earnings from ticket sales to people of minority origins.

From 1960 to 2050, it is projected that the composition of whites in the population of the USA will fall from 85 per cent to 47 per cent with that of minority groups rising from 15 per cent to 53 per cent in the same period. According to DIVRSITY FACTS (2020)/Hollywood Report (2020), out of the top 10 movies of 2018, six were by people of colour. In 2019, the DIVERSITY Report found out that 8 out of 10 top films were bought by minorities. It was concluded from the Report that diverse audiences required diverse casts in movies.

6.3.6 Implications of Diversity Management for Education and Human Resource Management

Embedding diversity, according to Mullins (2010:156), leads to self-reflection of attitudes, values, beliefs, and actions that will cause pain and trauma to others and it builds empathy and goodwill. Thus, implementing diversity and inclusiveness will stop stereotyping at the workplace and improve how people perceive one another since this is a small world of multiple interdependencies and mutual coexistence. Benefits gained from accepting change in this direction may include accepting to be different and unique, and protecting our heritage entrusted to us by our ancestors. Mullins (2010:154) bemoans the fact that the negative aspect of diversity is that it diminishes cultural relatedness or staying within our cultural enclaves to preserve our purity, and that extra costs are incurred in teaching managers to embrace diversity. Besides, there are extra costs incurred in having flexibility and shaping policy and imparting training to managers.

All these can jeopardize harmony as it will rock the boat and create conflicts. Mullins (2010) ends by stating that implementing diversity requires a lot of time, effort, and high commitment from top management who should create space for it and also create supportive structures by appointing a Diversity Relations Officer. In the USA, it has been observed that top management in both private and public sectors are under-represented by the demographic composition of the population as minority groups are represented by only $17 \%$ in many cases (NYU Wagner, 2010, passim). The USA is a melting pot of many nationalities but its leadership does not reflect its population composition (NYU Wagner, 2010, passim). This anomaly must change for the better. 
Diversity means having different things or a variety of different things. At the workplace of today, in many Multinational Corporations (MNCs) whose operations span the five continents, it is imperative for them to manage their workforce which comprises people of diverse nationalities from different backgrounds. By doing so, MNCs gain competitive advantage over their rivals as they project the image of being caring organisations. Besides, managing diversity is imperative for attaining industrial harmony and erasing all forms of discrimination and subtle ways of manipulating people based on their being different (Doz et al., 1981; Kogut, 1985; Prahalad, 1976, Thompson, 1967; Gennard \& Judge, 2005).

Being different is not a crime because we have to accept people the way they are and the way they perceive the world, and do things. If an MNC does not accept to manage diversity and were to standardize procedures and treat every employee the same way, then there would be room for complaints as many employees would not appreciate the standards in the sense that standards often are imposed from above based on the whims and caprices of a few policy makers. Imposition of standards means that employees are not allowed to participate in decision making. However, culture plays a big role in diversity management as in power cultures high power distance is accepted just as it is in high-context societies they do not suppress their emotions (Foot \& Hook, 2011; Brewster, et al. 2011; Schneider et al., 2003; Thomas \& Petersen, 2015).

Non-recognition of diversity in the workplace can be a recipe for discontent, low productivity and lack of job satisfaction. Each individual in the world is different and unique with unique identity. We should agree to accept people the way they are and also to be tolerant of their attitudes, behaviours and their unique personalities. Individual differences cannot be ignored in the workplace and these should not be seen as impediment to progress or platform for conflict within the organisation. In fact individual differences should be seen as strengths for an organisation to exploit because we can ride on their differences to assign them roles which befit their demeanour and character traits (Bassett-Jones, 2005).

We can assign extroverts as cheer leaders and marketers while introverts can work as researchers and back-office workers. Personalities come in different forms such as Sanguine, Melancholic, Choleric, and Phlegmatic. We can also use Myers-Briggs Personality Test to identify the diverse forms of personalities that we have in the workplace. Knowing about the diversity of the workforce helps us adjust our ways on how to handle interpersonal relationships and communication without creating friction and conflict.

Also the diversity of the workforce forces us to do self-examination or introspection so that we watch our actions and utterances so as to be ethical and legal in our behaviours towards one another (Fassinger, 2008). It is a great opportunity for learning from one another in a diverse, multi-racial, multi-ethnic and multidisciplinary workforce environment. Many MNCs recognise and celebrate the diversity of their workforce and they use this in their adverts and sales as selling points to show that they are non-discriminatory, that they embrace diversity and encourage people to be who they are, in effect stating that they respect human rights, promote equal rights, and they champion equity, fairness, equal opportunities, the rule of law and transparency. 
Multi-racial organisations provide opportunities for cultural diffusion, cross-fertilisation of ideas and inter-cultural unity. Diversity management ensures inclusivity whereby no one is left behind or excluded from the scheme of things. Recognition of diversity in an organisation means that no one is discriminated against on the basis of age, race, gender, religion, ethnic background, political party affiliation, disabilities, minority group, sexual orientation, among other differentiating factors.

Managing diversity means our recruitment policies should be directed at employing a representative group of the national population.

Managing diversity in the workplace imposes its own costs such as employing many welfare officers and counsellors, coaches and interpreters (Beham et al., 2012). Edward de Bono came up with his colour-coded Six Hats of Understanding to show how humans interpret issues from different perspectives. This can be an analogy for managing diversity. Also Honey \& Mumford stated that people have different styles of learning, ranging from Idealists to Pragmatists, Realists, Action-Centred people, and Reflectors. In training employees, we need to take this into consideration.

Howard Gardner came up with his 9 Multiple Intelligences as he stated that we are differently endowed and talented with many talents and approaches such as having diverse intelligences namely motor, musical, logical, aesthetic, social, spatial, and linguistic abilities. If we become aware of these innate abilities, then we will respect people as everyone has a special talent to contribute to the productivity of the organisation. No human being is a liability as everyone has a talent and is an asset to be exploited.

Some experts stated that there are four types of workers namely Eager Beavers, Mercenaries, Scivers, and Freeloaders or Looters. Eager Beavers stay long in the organisation and contribute a lot to it. Mercenaries have high labour turnover and short tenure but are highly productive. Freeloaders stay for a long time contributing very little to output. Finally, Scivers stay shortest and contribute very little to output. We should try to train and nurture all employees to become Eager Beavers through counselling, coaching, training, and staff development programmes.

In conclusion, managing diversity is the art of accepting differences and turning those differences into assets for the organisation.

\subsubsection{Some Case Studies of Diversity Management in the Educational Sector}

We observed during our course of work as Tutors at a known International School in Lusaka, Zambia that in that elite school, where at one time the student population comprised 62 nationalities, excluding the tutors who came from countries such as New Zealand, France, UK, India, Colombia, Spain, USA, Ghana, Uganda, Belgium, Netherlands and Egypt among others, there were instances where special education support was given to weak students and students with language and learning difficulties and disabilities such as those from non-English speaking countries. The support unit was called English as a Second Language (ESL). Those students who were identified with poor English writing and speaking skills had access to special tutor support during exams and lessons in class to help them cope. 
They were given access to bilingual dictionaries as well as interpreters. This was obviously at enormous cost to the institution which believed in excellence, inclusivity and diversity management. One of us spent almost a decade teaching in junior secondary schools in rural parts of South-West Nigeria in Ogun State. He found the students to be extremely raw with no chance of communicating in English. He had no option but to learn the local Yoruba language in order to teach the students Geography. This informs us that inclusivity and diversity management require innovation, adaptability and making sacrifices in order to achieve objectives set.

Currently at ZCAS University, we came across a student from Ethiopia who is struggling to cope with her course in Business Communication and Academic Writing. She explained that in her country they study English and use Amharic, their national lingua franca so she is weak in English. This means that our university has to come up with a special bridging up programme to cater for such foreign students who are disadvantaged because of language barrier. As a new university, we lack resources for such student support (cf. Bloom, 1956).

There are other students who struggle with Quantitative Methods or numerical subjects. Since in Zambia students do not enter university with A Levels or IB qualifications, there is a big knowledge gap which requires bridging in order to bring closure and ensure learning objectives are achieved timeously. All these point to the need to manage diversity and to bring about inclusiveness. In one of the MBA post-graduate classes, we found a student from a neighbouring French-speaking country who is struggling to cope with lectures being delivered in English.

Besides that, through interviews and informal chats with our master's post-graduate students, we found out that those who register for the MBA programme are from diverse professional backgrounds such as architecture, banking, accounting, medicine, law, ICT, education, psychology, marketing, engineering and sciences. Many lack solid academic and traditional way of exposition as they are fond of using bullet points without the usual way of approaching the writing of formal analytical essays.

Therefore, we found out that we had an uphill task of managing diversity and helping students to achieve the high levels of excellence required by academic rigour, rigmarole and scholarship. As lecturers, we need to be accommodative, empathetic, and innovative without compromising the high standards required of us.

\section{Conclusion and Recommendations}

In this article, we highlighted the meaning of Diversity Management and also vocabulary related to it. We also gave the characteristics of Diversity Management as well as best practices of Diversity Management in elite universities and selected multinational corporations. We gave practical examples of Diversity Management from our world of experience in the classroom. We also used the composition of the labour force in some selected MNCs and organisations to illustrate the concept of Diversity Management. It was clear in the discussions and findings in this paper that firms and organisations which gloss over the concept of Diversity Management do so at their own risk as practising DM has great 
potential for bestowing manifold benefits on any organisation that practices it. The findings indicate that the pressure brought to bear by government legislation and policies as well as the efforts of international multilateral institutions such as the UN, EU and AU make it clear that organisations have no choice but to embrace the concept of universal inclusion or diversity management if they want their operations to be sustainable in the long run, and also responsive to the changing demographic dynamics and fast-paced technological innovations.

\subsection{Recommendations}

- Diversity Management in organisations and institutions should be made compulsory and non-negotiable as that will give thrust and accelerate the implementation of the UN Sustainable Development Goals (SDGs)

- Diversity Management should be raised to the status of a university discipline and be taught at master's level at the university to raise its profile and also to give it eminence

- The UN agencies should institute special awards to be given to global diversity change agents and champions (DCAC) who will drive and implement diversity policies in their organisations in order to put diversity matters in the public domain

- Conferences, workshops, and training sessions should be organised throughout the world to empower people in order to be able to deal with diversity matters efficiently

- Following the Black Lives Matter Movement in the USA, the UN should set aside a day in the year to celebrate the Diversity of people and to prick the conscience of the world for people to realise the need to dispense fair treatment to minorities and disadvantaged groups

- Since diversity management encompasses a wide field such as gender balance, demographic justice, biodiversity, social justice, political inclusion, economic empowerment, technological know-how, green computing, smart cities, and many more, interdisciplinary and multidisciplinary approaches should be encouraged in crafting diversity programmes of study in the universities

- UNESCO and other interested agencies and institutions should be encouraged and should be adequately funded to support efforts in preserving minority languages which are in danger of becoming extinct. This will help preserve and improve global diversity of tribes as each ethnic group has something special to contribute to human endeavours

- Multinational corporations of the world should be actively engaged by the UN for them to diversity their recruitment practices so that they create chances for people from disadvantaged groups to be employed by them. This can be done by giving them a quota similar to the gender 50/50 standard which has been set for all organisations and institutions. By 2030, there should be people from 
many under-represented groups being employed as CEOs and Director-Generals in multilateral institutions and MNCs as part of the UN SDGs

\section{Acknowledgement}

We will like to salute our Supervisors at ZCAS University, particularly our DVC, Dr Kelvin Kayombo, for his encouraging words of wisdom and his strenuous and indefatigable efforts in restoring us to financial equilibrium by processing our claims for reimbursement of our publishing costs. We hope that in the not too distant future, ZCAS University will vote an annual research fund for each lecturer to utilise in pursuing research efforts. We also ardently hope that ZCAS University will work stridently in attracting massive research funds from external sponsoring institutions and agencies. We will also at this juncture like to express our gratitude to Dr Egret Lengwe, Director of Research, Consultancy and Innovation (DRCI) for sparing no effort to egg us on to continue publishing or else we perish. We will also like to thank all our post-graduate cohorts, some of whom have become our friends and mentees for offering us their great company. Finally, we will like to thank all our workmates who give us moral support.

\section{References}

Al-Rodhan. (2006) Program on the Geopolitical Implications of Globalisation and Transnational Security.

Anca, C., \& Vazquez, A. (2007) Managing Diversity in Global Organisations: Creating new Business values London: Palgrave Macmillan.

Armstrong, M. (2014) Armstrong's Handbook of Human Resource Management Practice (13th ed.) London: Kogan Page.

Atiyah, L. A. R. (2016) Cross-Cultural Management Journal Vol. XVIII Issue 2, 2016.

Banks, K. H. (n.d.). Diversity in Leadership Psychology Today.

Bartlett, C. A., \& Ghoshal, S. (1987). Managing across Borders: New Strategic Requirements Sloan Management Review (SMR) 45, fall 1987 Harvard Business School \& INSEAD.

Bassett-Jones, N. (2005). The Paradox of Diversity Management-Creativity \& Innovation Creativity and Innovation Management, 14(2), June 2005. https://doi.org/10.1111/j.1467-8691.00337.x

Beham, B., Straub, C., \& Schwalbach, J. (2012) Managing Diversity in Organisations: Switzerland: Springer. https://doi.org/10.1007/978-3-8349-3869-5

Bloom, B. S. (1956). Taxonomy of Educational Objectives Handbook 1 New York: Addison Wesley Publishing Company.

Brewster, C., Sparrow, P., Vernon, G. \& Houldsworth, E. (2011) International Human Resource Management (3rd ed.) London: CIPD. 


\section{Macrothink}

International Journal of Human Resource Studies ISSN 2162-3058 2021, Vol. 11, No. 1

Byars, L. \& Rue, R.W. (1997) Human Resource Management Chicago: Richard Urwin-Times Mirror Higher Education Group Inc. pp. 8-10.

CFI Education Inc. (2020) Diversity Management [Online] Retrieved from Corporate Finance Institute (CFI)https://corporatefinanceinstitute.com/resources/knowledge/other/diversity-management/ \#: :text=Diversity\%20management\%20refers\%20to\%20organizational

Coleman, P. T., Deutsch, M., \& Marcus, E. C. (2014) (eds.) The Handbook of Conflict Resolution - Theory and Practice (3rd ed.) New York, N.Y.: Jossey-Bass/John Wiley

Dessler, G., Rekar, M. C., \& Cole, N. D. (2011) Management of Human Resource Ontario: Pearson Education.

DIVERSITY FACTS (2019) How Coca Cola Supports Inclusion and Equality for the LGBTQ Community (2019).

DIVERSITY FACTS (2020) Columbia International Students and Scholars Office-ISSO 2019-2020 Overview Institute of International Education (IIE) [Online].

DIVERSITY FACTS (2020). Hollywood and the Future of Work [Online].

DIVERSITY FACTS MIT Diversity Racial Demographics MIT Student Population Statistics and Why Diversity Matters [Online].

DIVERSITY FACTS. (2020). Nine Ways we're making Unilever a more gender-balanced Business [Online].

DIVERSITY FACTS/Coca Cola Company-Statistics \& Facts_Statista.html

DIVERSITY FACTS/Harvard International Students-Information on International Students [Online]

DIVERSITY FACTS/Nine Ways we're making Unilever a more gender-balanced business News Unilever-East \& West Africa.html

DIVERSITY FACTS/Toyota number of employees 2020_ Statista.html

DIVERSITY FACTS/Yale Demographics: How Diversity is and Diversity makes a Difference [Online] Retrieved from DIVERSITY FACTS/Yale University Diversity-Racial Demographics \& Other Stats.html

DMC PRAGUE Leadership and Developing Diversity and Inclusion

Doz, Y. L., \& Prahalad, C. K. (1981) Headquarters' Influence and Strategic Control in Multinational Corporations Sloan Management Review (SMR) Fall, 1981 pp. 15-30.

Espey, J., Walecik, K. \& Kuhner, M. (2015) Follow-up and Review of the SDGs: Fulfilling our commitments- Sustainable Development Solutions Network (SDSN)

Fassinger, R. (2008) Workplace Diversity and Public Policy-Challenges and Opportunities for Psychology American Psychologist May 2008 Festinger's Cognitive Assonance and 
Dissonance. https://doi.org/10.1037/0003-066X.63.4.252

Foot, M., \& Hook, C. (2011) Introducing Human Resource Management. (6th ed.). London: Prentice Hall.

Gavin, M. (2014) Why cultural diversity matters Nov. 7, 2014 Retrieved from youtube.com/watch?v=48Ri0ddRU

Gennard, J. \& Judge, G. (2005) Employee Relations (4th ed.). London: CIPD.

Greenberg, J. (2010) Diversity in the Workplace. Benefits, Challenges and Solutions.

Groysberg, B., \& Connolly, K. (2013). Great Leaders Who Make the Mix Work Harvard Business Review, 91(9) (September 2013): 68-76.

Halle, M., \& Wolfe, R. (n.d.) Architecture for review and follow-up of the SDGs: Options for the High Level Political Forum. International Institute for Sustainable Development (IISD).

House, R. J., Hanges, P. J., Javidan, M., \& Dorfman, P. W., \& Gupta, V. (2004) Culture, Leadership and Organization, (The) GLOBE Study of 62 Societies, Thousand. Oaks, CA: Sage.

House, R. J., Javidan, M., Hanges, P., \& Dorfman, P. (2002). Understanding cultures and implicit leadership theories across the globe: an introduction to project GLOBE. Journal of World Business, 37, 3-10.

Inegbedion, H., Sunday, E., Asaleye, A., Lawal, A., \& Adebanji, A. (2020) Managing Diversity for Organizational Efficiency Sage Open Jan-March 2020, pp. 1-10

International Council for Science/International Social Sciences Council (ICSU/ISSC) (n.d.)

Johnson, G., Scholes, K., \& Wittington, R. (2017) Exploring Corporate Strategy UK: Pearson Education.

Kamoche, K. N. (2001) Understanding Human Resource Management Buckingham: Open University Press pp. 92-110 (IHRM).

Kearney, E., \& Voelpel, S. C. (2012) Diversity Research- What do we currently know about how to manage diverse organisational units?

Kogut, B. (1985). Designing Global Strategies-Profiting from Operational Flexibility Sloan Management Review (SMR) fall, 27-38.

Leadership development and inclusion https://us.search.yahoo.com/yhs/search?hspart=blp\&hsimp=yhs-default\&type=ds_111_674_0 $\& \mathrm{p}=$ leadrship+development+and+inclusion\&rnd=1466336199\&param1

Melville, D. (2015) Improving your diversity IQ- TEDxSyracuseUniversity, May 1, 2015 Retrieved from youtube.com/watch?v=WuWmKDmJoPg

Mondy, R. W., Noe, R. M., \& Premeaux, S. R. (2002). Human Resource Management, (8th ed.). New Jersey: Pearson Education. 
Mullins, L. J. (2010) Management and Organisational Behaviour (9th ed.) London: FT-Prentice Hall chapters. 7. 8, 9, and 19.

Nadler, L. (1984). The Handbook of Human Resource Development New York: John Wiley \& Sons NYU Wagner (2010). Leadership, diversity and inclusion-insights from scholarship

https://wagner.nyu.edu/files/leadership/LeadershipDiversityInclusionScholarship.pdf

Omedien, J., Rapp, M. S., \& Wolff, M. (2012) Women on German Management Boards. How Ownership Structure Affects Management Board Diversity Springer

Patrick, H. A., \& Kumar, V. R. (2012) Diversity Management Sage Open April-June 2012 $1-15$.

Perkins, S. J., \& White, G. (2008) Employee Reward Alternatives, Consequences and Contexts London: CIPD Harlow, Essex: Pearson Publishing.

Prahalad, C. K. (1976). The Strategic Process in a Multinational Corporation Boston: Harvard Business School unpublished doctoral thesis 1976.

Princeton University (2020) Facts and Figures [Online].

Review of targets for SDGs: The Science Perspective issc@worldsocialscience.org/secretariat@icsu.org

Robbins, S. P., \& Judge, T. A. (2019). Organizational Behaviour (15th ed.) Harlow, Essex: Pearson Publishing.

Rollinson, D. (2008). Organisational Behaviour and Analysis London: FT Prentice Hall

Rose, E. (2008). Employment Relations (3rd ed.). Harlow, Essex: FT-Prentice Hall

Sachs, J. D. (2012). From MDGs to SDGs (The) Lancet June 9, 2012, Vol. 379.

Saxena, A. (2014). Workforce Diversity- A key to Improve Productivity Symbiosis Institute of Management Studies Annual Research Conference Procedia Economics \& Finance Vol. 11 2014, pp. 76-85 www.elsevier.com/locate/procedia

Schafer, S., Kearney, E., Voelpel, S. C., \& Koester, R. (2012) Managing Demographic Change and Diversity in Organisations: How feedback from Co-workers Moderate the Relationship between Age and Innovative Work Behaviour Switzerland: Springer.

Schneider, S. C., Barsoux, J-L., \& Stahl, G. K. (2003) Managing Across Borders (3rd ed.) London: Pearson.

Sharma, U. (2016) Managing Diversity and Cultural Differences at Workplace IPE Journal of Management, 6(2), July-Dec. 2016, pp. 63-79.

Spiegel, M. R. (1975) Probability and Statistics Singapore: Schaum's Outline Series, McGraw Hill Book Company.

Starling, G. (2008) Managing the Public Sector Boston, MA: Thomson-Wadsworth chp. 10 
pp. 443-4891.

Statista (2020). Coca-Cola Company Statistics \& Facts Jan Conway December 2020.

Statista. (2020). Consolidated number of Toyota Motor Corporation Employees from FY2012 to FY 2020 [Online] Wagner June 2020.

Stegmann, S., Roberge, M., \& Dick, R. (2012). Getting tuned in to those who are different. The role of empathy as mediator between diversity and performance Switzerland: Springer.

Thomas, D. C., \& Peterson, M. F. (2015) Cross-Cultural Management-Essential Concepts (3rd ed.) London: Sage Publications.

Thompson, J. D. (1967) Organisations in Action New York: McGraw Hill.

Torrington, D., Hall, L., Taylor, S., \& Atkinson, C. (2011). Human Resource Management, (8th ed.) London: Pearson Education.

UCLA. (2019). UCLA 2018-19 Undergraduate Profile- New Freshmen and Transfers [Online] Retrieved from studentsurveyuniversityofcalifornia.edu

UCLA. (2020). Hollywood Diversity Report 2020- A Tale of Two Hollywood: UCLA Institute for Research on Labour \& Employment/College of Social Sciences.

UN. (2015) Transforming our World: The 2030 Agenda for Sustainable Development A/RES/70/1 sustainabledevelopment.un.org

University of Cambridge. (2019). Facts and Figures January 2020 [Online].

University of Oxford. (2020). Facts and Figures-Full Version- Oxford at a Glance [Online].

Urbancova, H., Hudakova, M., \& Fajcikova, A. (2020) Diversity Management as a Tool of Sustainability of Competitive Advantage Sustainability, MDPI (Online) 2020 Dec 5020 pp. $1-16$.

US Bureau of Labour Statistics. (2017). Retrieved from blsgov/opub/reports/race-and-ethnicity/2017/pdf/home.pdf

Weightman, J. (2004). Managing People (2nd ed.). London: CIPD chps. 13 and 14.

Wolf, E., Beblo, M., \& Ohlert, C. (2012) Gender and Nationality Pay Gaps in Light of Organisational Theories- A large Scale Analysis within German Establishments Switzerland: Springer.

\section{Notes}

We hope that this article will immensely benefit all undergraduate and postgraduate students pursuing courses in International Human Resource Management, Conflict Resolution, Managing People Across Borders, among others, and those who work as expatriates, diplomats and practitioners in international organisations such as ILO, CIPD, UN and other agencies as well as in International Human Resource Management (IHRM) in connection 
with expatriates working for Multinational Corporations (MNCs).

\section{Copyright Disclaimer}

Copyright for this article is retained by the author(s), with first publication rights granted to the journal.

This is an open-access article distributed under the terms and conditions of the Creative Commons Attribution license (http://creativecommons.org/licenses/by/4.0/). 